\title{
OIL PALM ECONOMIC PERFORMANCE IN MALAYSIA AND R\&D PROGRESS IN 2018
}

\author{
KUSHAIRI, A*; MEILINA ONG-ABDULLAH*; BALU NAMBIAPPAN*; ELINA HISHAMUDDIN*; \\ MOHD NOOR IZUDDIN ZANAL BIDIN*; RAZMAH GHAZALI*; VIJAYA SUBRAMANIAM*; \\ SHAMALA SUNDRAM* and GHULAM KADIR AHMAD PARVEEZ*
}

\begin{abstract}
Staying resilient is probably an understatement for the oil palm industry during the period of 2018. Whilst other sectors such as the electrical and electronics and other manufactured products were experiencing a bullish growth, the export value of palm oil and palm oil-based products was on the decline. This is essentially due to the looming threat of a total ban of palm oil-based biodiesel by the European Union (EU) come 2021 and the higher production from palm oil plantations in Indonesia causing lower demand and oversupply worldwide. In view of the former, Malaysia's export market scene is expected to change in the coming years. Malaysia has since identified several potential new markets in Africa, Central and South Asia. The negative campaigns relating to health, social or environment targeted at the oil palm are not new but the current action led by the West is clearly causing a major dent in the industry. As the most traded commodity, the industry as a whole is constantly subjected to scrutiny with environment being the current key issue warranting the imposition of checks and balances such as the Malaysian Sustainable Palm Oil (MSPO), Indonesian Sustainable Palm Oil (ISPO) and Rountable Sustainable Palm Oil (RSPO) certification. At the same time, every aspect of the research continues to progress further building on prior knowledge arising directly from working on the oil palm or through model systems. Their progress is briefly highlighted in this review. Clearly the main theme of the research from upstream to midstream and finally downstream are basically aligned with and directed towards achieving the Sustainable Development Goals (SDG) by 2030. This would consequently help further improve the perception of oil palm/palm oil in general.
\end{abstract}

Keywords: palm oil, sustainable, smallholders, biomass, bioenergy, food and nutrition, oleochemicals, technology.

Date received: 19 April 2019; Sent for revision: 22 April 2019; Received in final form: 11 June 2019; Accepted: 12 June 2019.

\section{INTRODUCTION}

The year 2018 was indeed a challenging year for the Malaysian oil palm industry with lower palm oil production, exports and prices. Production of crude palm oil (CPO) in 2018 declined as compared to the previous year's performance in line with lower fresh fruit bunch (FFB) yield due to stress on

Malaysian Palm Oil Board, 6 Persiaran Institusi,

Bandar Baru Bangi, 43000 Kajang, Selangor, Malaysia.

E-mail: parveez@mpob.gov.my oil palm after experiencing high yield performance in 2017 and unpredictable rainy season which affected harvesting activities. Lower palm oil prices and weak demand resulted in the decline of export earnings to RM 65.12 billion as compared to RM 74.75 billion in 2017. Aside from the gloomy outlook on the economics front for the oil palm sector, a more disturbing issue faced by the industry early in the year was the proposed phasing out of palm oil as transport fuel in the European Union (EU) by 2021. This caused an uproar in palm oil producing countries, mainly Indonesia and Malaysia, as both 
countries contribute $85 \%$ of the global palm oil supply, which accounted for $34 \%$ of world vegetable oils consumption in 2018. As the EU is one of the world's top consumers of palm oil, the ban would certainly hurt the industry as a whole. The EU proclaimed that its action is justified in order to stop deforestation of the rainforest and to evade further loss in biodiversity. However, as we now know that the livestock industry caused the most harm to the environment (Basiron and Yew, 2015). Sustainable oil palm practices encompassing the whole value chain have since become the sine quo non for the industry. In fact, the plan for Malaysia to fully implement the mandatory Malaysian Sustainable Palm Oil (MSPO) certification across the board by end of 2019 speaks for itself. Having proven to be the 'golden crop' that can significantly accelerate social and economic development (World Growth, 2011; Pacheco et al., 2017; Nambiappan et al., 2018), whilst causing the least impact on land use in comparison to other oilseed crops (Anderson, 2008; Miller, 2015; D' Enghein, 2016). In addition, responsible and well-conducted oil palm cultivation has the potential to positively sequester carbon (Leblanc and Russo, 2008; Anderson, 2008) and support biodiversity (Fitzherbert et al., 2008; Anderson, 2008; Teuscher et al., 2016). As a perennial crop (Kahn et al., 2011), the competitive edge that the oil palm provides surpasses other oilseed crops thus, curbing its use via a ban based on reasons that are regarded as baseless and not substantiated is deemed as an act of protectionism and politically motivated. Nonetheless, while the trade issue is being addressed, the R\&D now plays a vital role in data generation and to authenticate the viability of the industry.

This review highlights the general performance of the industry for 2018 and discusses some of the key results reported on research, ranging from upstream to downstream mainly tackling sustainable issues confronting the industry. It is evident that technology plays a major role in driving sustainability.

\section{PERFORMANCE OF MALAYSIAN OIL PALM INDUSTRY}

In 2018, Malaysia's oil palm industry showed an unfavourable performance as against the 2017 performance (Table 1). FFB yield, CPO production and palm oil exports decreased, while imports of palm oil increased and palm oil stocks closed higher. Higher carry-over stocks, higher palm oil imports and lower exports, pushed palm oil stocks to reach above 3 million tonnes as at end of December 2018. Weaker vegetable oil prices took a toll on the CPO price, thereby affecting export revenue (Kushairi and Balu, 2018).

CPO production in 2018 witnessed a decline of 2.0\% to 19.52 million tonnes as against 19.92 million tonnes recorded in 2017. The lower CPO production in 2018 was mainly due to lower FFB processed by $3.2 \%$ to 97.80 million tonnes arising from lower FFB yield performance, i.e. declined by $4.1 \%$ to $17.16 \mathrm{t}$ $\mathrm{ha}^{-1}$ as against $17.89 \mathrm{t} \mathrm{ha}^{-1}$ in 2017. Weak demand from importing countries, especially Vietnam, Egypt and the EU reduced palm oil intake by 0.07 million tonnes or $0.4 \%$ to 16.49 million tonnes from 16.56 million tonnes registered in 2017. The lower volume of oil palm products traded in 2018 reduced export earnings of these products. On the contrary, importation of palm oil, which was mostly from Indonesia had surged by $51.3 \%$ to 0.84 million tonnes as against 0.56 million tonnes in 2017.

In the supply and demand scenario, opening stocks for 2018 was higher by $63.9 \%$ or 1.07 million tonnes to reach 2.73 million tonnes vis-à-vis 1.67 million tonnes for 2017. Peninsular Malaysia and Sabah recorded lower CPO production as compared to 2017 , a decline of $3.6 \%$ and $1.5 \%$ respectively to 10.20 million tonnes and 5.14 million tonnes down from 10.58 million tonnes and 5.22 million tonnes. The lower $\mathrm{CPO}$ production for both regions was associated with lower FFB processed arising from lower FFB yield performance. FFB processed in Peninsular Malaysia was down by $5.9 \%$ to 51.80

TABLE 1. MALAYSIAN OIL PALM INDUSTRY PERFORMANCE

\begin{tabular}{lrrcc}
\hline & 2018 & 2017 & \multicolumn{2}{c}{ Difference } \\
\cline { 4 - 5 } & & & Vol./value & $\%$ \\
\hline Opening stocks (mil tonnes) & 2.73 & 1.67 & $(0.07$ & 63.9 \\
CPO production (mil tonnes) & 19.52 & 17.92 & $(0.73)$ & $(2.0)$ \\
FFB yield (t ha ${ }^{-1}$ ) & 17.16 & 19.72 & 0.23 & $(4.1)$ \\
Oil extraction rate (\%) $_{\text {PO exports (mil tonnes) }}^{19.95}$ & 16.56 & $(0.07)$ & $(0.4)$ \\
PO imports (mil tonnes) & 16.49 & 0.56 & 0.29 & 51.3 \\
Closing stocks (mil tonnes) & 0.84 & 2.73 & 0.48 & 17.7 \\
CPO price (RM t ${ }^{-1}$ ) & 3.22 & 2783.00 & $(550.50)$ & $(19.8)$ \\
Export revenue (RM billion) & 232.50 & 74.75 & $(9.63)$ & $(12.9)$ \\
\hline
\end{tabular}

Note: $\mathrm{CPO}$ - crude palm oil, FFB - fresh fruit bunch, PO - palm oil, mil tonnes - million tonnes. Source: MPOB (2019). 
million tonnes from 55.04 million tonnes in 2017. In Sabah, FFB processed declined by $1.5 \%$ to 24.95 million tonnes from 25.32 million tonnes in the previous year. Meanwhile, CPO production in Sarawak had recorded an increase of $1.2 \%$ to 4.18 million tonnes from 4.13 million tonnes in 2017 due to higher FFB processed by palm oil mills which increased to 21.05 million tonnes from 20.66 million tonnes in 2017 attributed to an increase in the matured area in 2018 (Table 2).

The FFB yield declined significantly in 2018, down by $4.1 \%$ to $17.16 \mathrm{t} \mathrm{ha}^{-1}$ as against $17.89 \mathrm{t} \mathrm{ha}^{-1}$ in 2017 (Table 3). The decrease in FFB yield performance was due to the stress on oil palm after experiencing high yield in 2017 and an unpredictable rainy season which affected harvesting activities. FFB yield for Peninsular Malaysia decreased by $6.7 \%$ to $17.44 \mathrm{t}$ ha $^{-1}$ as against $18.70 \mathrm{t} \mathrm{ha}^{-1}$ in 2017. Sabah's FFB yield registered a decline of $1.0 \%$ to $18.16 \mathrm{tha}^{-1}$ as against $18.35 \mathrm{t} \mathrm{ha}^{-1}$. Meanwhile, the yield performance that of Sarawak was equally lower at $15.74 \mathrm{tha}^{-1}$, down by $2.4 \%$ as compared to $16.13 \mathrm{t} \mathrm{ha}^{-1}$ in 2017 .

In terms of oil extraction rate (OER) performance, Malaysia's OER in 2018 saw an increase of $1.2 \%$ to $19.95 \%$ from $19.72 \%$ achieved in 2017 (Table 4). The

TABLE 2. MALAYSIAN CPO PRODUCTION (t)

\begin{tabular}{|c|c|c|c|c|}
\hline & \multirow[t]{2}{*}{2018} & \multirow[t]{2}{*}{2017} & \multicolumn{2}{|c|}{ Difference } \\
\hline & & & Vol. & $\%$ \\
\hline Peninsular Malaysia & 10.20 & 10.58 & $(0.38)$ & (3.6) \\
\hline Sabah & 5.14 & 5.22 & $(0.08)$ & (1.5) \\
\hline Sarawak & 4.18 & 4.13 & 0.05 & 1.2 \\
\hline Malaysia & 19.52 & 19.92 & $(0.40)$ & $(2.0)$ \\
\hline
\end{tabular}

Note: CPO - crude palm oil.

Source: MPOB (2019).

TABLE 3. MALAYSIAN FFB PRODUCTIVITY $\left(\mathrm{t} \mathrm{ha}^{-1}\right)$

\begin{tabular}{lccc}
\hline & $\mathbf{2 0 1 8}$ & $\mathbf{2 0 1 7}$ & Difference (\%) \\
\hline Peninsular Malaysia & 17.44 & 18.70 & $(6.7)$ \\
Sabah & 18.16 & 18.35 & $(1.0)$ \\
Sarawak & 15.74 & 16.13 & $(2.4)$ \\
\hline Malaysia & 17.16 & 17.89 & $(4.1)$ \\
\hline
\end{tabular}

Note: FFB - fresh fruit bunch.

Source: MPOB (2019). higher OER performance in 2018 was mainly due to better quality of FFB received and processed by the mills as compared to that of in previous year. Peninsular Malaysia recorded 2.5\% higher OER vis-à-vis 2017 performance to reach 19.69\% from $19.21 \%$. OER performance in Sarawak, however, declined by $0.7 \%$ to $19.85 \%$, while Sabah recorded the same level of OER as achieved in 2017, at 20.60\%. The decline in OER performance in Sarawak was due to the lower quality of FFB received and processed by palm oil mills arising from higher volume of FFB supplied from new matured areas.

Exports of oil palm products in 2018 were higher by $3.5 \%$ to 24.82 million tonnes as compared to 23.97 million tonnes in 2017. This was mainly attributed to higher export volume of other oil palm products (Table 5). The lower palm prices traded in 2018, however, had contributed to the significant decline in total export value, down by $12.9 \%$ to RM 65.12 billion from RM 74.75 billion in 2017. Exports of palm oil declined marginally by $0.4 \%$ to 16.49 million tonnes from 16.56 million tonnes in 2017 due to weaker demand, especially from Vietnam, Egypt and EU. Similarly, palm oil export value was lower by $17.9 \%$ to RM 41.04 billion from RM 50.01 billion in 2017. The lower prices of all oil palm products traded in 2018 were influenced by the higher palm oil stocks (of more than 3.0 million tonnes) arising from weaker palm oil exports and higher imports, coupled with weaker prices of other vegetable oils in the world market.

Malaysian palm oil exports in 2018 were destined largely to the traditional markets similar to that in 2017, namely India, the EU, China, Pakistan, to name a few. Since 2014, India has maintained its

TABLE 4. MALAYSIAN OIL EXTRACTION RATE $(\%)$

\begin{tabular}{lccc}
\hline & $\mathbf{2 0 1 8}$ & $\mathbf{2 0 1 7}$ & Difference (\%) \\
\hline Peninsular Malaysia & 19.69 & 19.21 & 2.5 \\
Sabah & 20.60 & 20.60 & 0.0 \\
Sarawak & 19.85 & 19.98 & $(0.7)$ \\
\hline Malaysia & 19.95 & 19.72 & 1.2 \\
\hline
\end{tabular}

Note: OER - oil extraction rate.

Source: MPOB (2019).

TABLE 5. MALAYSIAN EXPORTS OF PALM OIL AND OIL PALM PRODUCTS

\begin{tabular}{lrrrrrrrr}
\hline & \multicolumn{3}{c}{ Vol. (t) } & & \multicolumn{3}{c}{ Value (RM billion) } \\
\cline { 2 - 3 } \cline { 7 - 8 } & \multicolumn{1}{c}{$\mathbf{2 0 1 8}$} & $\mathbf{2 0 1 7}$ & Difference (\%) & & $\mathbf{2 0 1 8}$ & $\mathbf{2 0 1 7}$ & Difference (\%) \\
\hline CPO & 3394522 & 2709398 & 25.3 & & 7.82 & 7.72 & 1.3 \\
PPO & 13092180 & 13850559 & $(5.5)$ & & 33.22 & 42.29 & $(21.4)$ \\
PO & 16486702 & 16559957 & $(0.4)$ & & 41.04 & 50.01 & $(17.9)$ \\
Others* & 8336737 & 7414569 & 12.4 & & 24.08 & 24.74 & $(2.7)$ \\
\hline Total & 24823439 & 23974526 & 3.5 & & 65.12 & 74.75 & $(12.9)$ \\
\hline
\end{tabular}

Note: CPO - crude palm oil, PPO - processed palm oil, PO - palm oil, PKO - palm kernel oil, PKC - palm kernel cake. ${ }^{*} \mathrm{PKO}, \mathrm{PKC}$, palm-based oleochemicals, biodiesel, finished products and others.

Source: MPOB (2019) 
position as the largest Malaysian palm oil export market with an intake of 2.51 million tonnes or $15.2 \%$ of total palm oil exports in 2018 (Table 6). Other major markets were the EU, which was the second largest at 1.91 million tonnes $(11.6 \%)$, followed by China, at 1.86 million tonnes $(11.3 \%)$ and Pakistan, at 1.16 million tonnes (7.0\%). Apart from that, the Philippines (4.2\%), Turkey (3.8\%) and USA $(3.3 \%)$ were amongst the major palm oil export destinations in 2018. These top seven markets combined accounted for 9.31 million tonnes or $56.5 \%$ of the total Malaysian palm oil exports in 2018.

In terms of market performance, the higher intake of palm oil by India, up by $23.9 \%$ to 2.51 million tonnes in 2018 from 2.03 million tonnes in 2017 was partly attributed to the lower import of soyabean oil, down by $18.1 \%$ to 2.87 million tonnes in 2018 from 3.50 million tonnes in 2017. The CPO export duty suspension policy implemented by Malaysia during January-April 2018, coupled with the nil CPO export duties (September-December 2018) was another contributing factor for the higher export volume to India in 2018. As a result of both policies, exports of $\mathrm{CPO}$ to India reached 1.87 million tonnes in 2018 as compared to 1.38 million tonnes in 2017. However, Malaysian palm oil exports to the EU and China declined by $4.0 \%$ and $3.0 \%$ respectively to 1.91 million tonnes and 1.86 million tonnes as against 1.99 million tonnes and 1.92 million tonnes in 2017. The decline in exports to the EU was due to higher import of soyabean oil, up by $14.9 \%$ to 0.32 million tonnes in 2018. Meanwhile, the higher uptake of Indonesian palm oil by $12.5 \%$ to 3.30 million tonnes and higher import of rapeseed oil by $65.9 \%$ to 1.16 million tonnes during JanuaryNovember 2018 were the contributing factors for the lower palm oil exports to China. Pakistan registered a $14.2 \%$ increase in Malaysian palm oil imports, with an intake of 1.16 million tonnes as a result of lower imports of soyabean from Brazil for crushing activities, down by $32.6 \%$ to $644000 \mathrm{t}$ in 2018 from $956000 \mathrm{t}$ in 2017.

TABLE 6. MALAYSIAN PALM OIL EXPORTS TO MAJOR DESTINATIONS $(t)$

\begin{tabular}{lrrrc}
\hline & 2018 & 2017 & \multicolumn{2}{c}{ Difference } \\
\cline { 4 - 5 } & & & Vol. & $\%$ \\
\hline India & 2514008 & 2028297 & 485711 & 23.9 \\
EU & 1911797 & 1991548 & $(79751)$ & $(4.0)$ \\
China & 1859748 & 1917288 & $(57539)$ & $(3.0)$ \\
Pakistan & 1161260 & 1016977 & 144283 & 14.2 \\
Philippines & 689238 & 751688 & $(62450)$ & $(8.3)$ \\
Turkey & 631887 & 679667 & $(47781)$ & $(7.0)$ \\
USA & 540509 & 554614 & $(14105)$ & $(2.5)$ \\
Others & 7178255 & 7619878 & $(441623)$ & $(5.8)$ \\
\hline Total & 16486702 & 16559957 & $(73255)$ & $(0.4)$ \\
\hline
\end{tabular}

Note: EU - European Union.

Source: MPOB (2019).
The decline in palm oil exports to the Philippines by $8.3 \%$ to 0.69 million tonnes was due to higher supply of coconut oil for domestic consumption. Lower palm oil intake by Turkey, down by $7.0 \%$ to 0.63 million tonnes in 2018 from 0.68 million tonnes in 2017 was attributed to higher imports of soyabean from Brazil for crushing activities, up by 4.9 -fold to 1.42 million tonnes during January-November 2018.

On the contrary, imports of palm oil in 2018 increased significantly by $51.3 \%$ to 0.84 million tonnes vis-à-vis 0.56 million tonnes in 2017 (Table 7). The commitment to fulfil palm oil contract obligations based on either Malaysian or Indonesian source of supply, coupled with the need to supplement lower palm oil supply availability in 2018 for the local processing sector were the contributing factors for the higher imports. Indonesia contributed $97.4 \%$ or 0.82 million tonnes from the 0.84 million tonnes of palm oil imports in 2018 and has remained as the major source of palm oil imports.

The higher palm kernel oil imports, up by $32.4 \%$ to $241026 \mathrm{t}$ in 2018 was to cater to the higher demand from the domestic oleochemical plants, up by 122078 t or $9.6 \%$ to 1.40 million tonnes. Similarly, imports of palm kernel rose sharply by 4.7 -fold to $79298 \mathrm{t}$ in 2018. Higher demand from the domestic crushing industry, driven by a $3.9 \%$ increase in export demand for palm kernel cake, attributed to the increase.

Meanwhile, palm oil closing stocks as at end of December 2018 was higher by 0.48 million tonnes or $17.7 \%$ at 3.22 million tonnes vis-à-vis 2.73 million tonnes recorded in December 2017 (Table 8). The higher closing stocks was mainly due to higher palm oil opening stocks, higher palm oil imports and lower palm oil exports. As at end of December

TABLE 7. MALAYSIAN IMPORTS OF OIL PALM PRODUCTS $(t)$

\begin{tabular}{lrrrc}
\hline \multirow{2}{*}{2018} & \multirow{2}{*}{2017} & \multicolumn{2}{c}{ Difference } \\
\cline { 3 - 5 } & & & \multicolumn{1}{c}{ Vol. } & $\%$ \\
\hline PO & 841452 & 556095 & 285357 & 51.3 \\
PKO & 241026 & 182106 & 58919 & 32.4 \\
Palm kernel & 79298 & 17028 & 62271 & 4.7 -fold \\
\hline Total & 1161776 & 755229 & 406547 & 53.8 \\
\hline
\end{tabular}

Note: PO - palm oil, PKO - palm kernel oil.

Source: MPOB (2019).

TABLE 8. MALAYSIAN PALM OIL CLOSING STOCKS $(t)$

\begin{tabular}{lrrrr}
\hline & December & December & \multicolumn{2}{c}{ Difference } \\
\cline { 4 - 5 } & $\mathbf{2 0 1 8}$ & $\mathbf{2 0 1 7}$ & Vol. & $\%$ \\
\hline Peninsular Malaysia & 1740048 & 1631374 & 108674 & 6.7 \\
Sabah & 978659 & 735975 & 242684 & 33.0 \\
Sarawak & 496345 & 364744 & 131601 & 36.1 \\
\hline Malaysia & 3215052 & 2732093 & 482959 & 17.7 \\
\hline
\end{tabular}

Source: MPOB (2019). 
2018, all regions in Malaysia had recorded higher closing stocks as compared to end of December 2017. Peninsular Malaysia recorded higher stocks, up by $6.7 \%$ to 1.74 million tonnes, Sabah up by $33.0 \%$ to 0.98 million tonnes, while Sarawak closed at 0.50 million tonnes, up by $36.1 \%$ (MPOB, 2019).

\section{R\&D FOCUS AREAS IN 2018}

\section{Sustainable Upstream}

Peat conservation in its pristine state was supported with three publications refuting some earlier publications that claimed peat conversion had its merits with lesser $\mathrm{CO}_{2}$ fluxes from oil palm plantations compared to peat swamp forest (Melling, 2005; 2012). Studies by Wijedasa et al. (2018), Dommain et al. (2018) and Khasanah and Noordwijk (2019) implicated the carbon emission found in oil palm plantations planted on peat was far more damaging than its pristine state. Wijedasa et al. (2018) went on further by suggesting Indonesian government to carry out legislation and policy in the country, which could in return provide a significant reduction in emission. Among the legislative moves includes the Indonesian moratorium that aims to reduce emissions through Reducing Emissions from Deforestation and Degradation (REDD) scheme that prohibits new concessions for industrial agriculture plantations and logging in primary forests and peatlands (President of Indonesia, 2011; Sloan et al., 2012). It has to be reiterated that a number of activities can reduce emission namely improved land use and spatial planning, sustainable forest management and restoration of degraded ecosystem (Republic of Indonesia, 2016). This is also possible provided if the steps of revised land use planning with the peat swamp forest (PSF) conservation and agricultural practices is based on the rehabilitation of peatland hydrological function were kept in mind. Agriculture is easily affected by global climate change and Dommain et al. (2018) claims to being the first to report the harmful effects of peat conversion using global warming potentials (GWP) and earth's radioactive budget. Despite the unpopular issues arising from peat conversion, microbial diversity in oil palm plantations showed positive significant difference in the number of microbial groups identified in comparison to peat swamp forest and logged-over forest (Mohd Shawal et al., 2018), respectively. The prokaryotic biodiversity profiled in matured oil palm plantations aided the rejuvenation of some bacterial population that were missing in the interim of forest clearing. Similarly, Berkelmann et al. (2018) confirmed that the bacterial community composition from rainforest to land use conversion for agricultural purposes (rubber and oil palm) was not affected. The study highlights that soil characteristics; $\mathrm{pH}$, base saturation, $\mathrm{Fe}$ content and C:N ratio were the significant drivers for the changes in bacterial composition. With mixed reviews on oil palm planting, the industry has to address the challenges and accusations while remaining sustainable at the same time.

Oil palm planted with adequate rainfall, sunshine and ideal soil conditions would in return contribute to optimal growth and yield projection. These factors along with recommended agrochemical applications and best management system will further enhance yield but it needs to be reiterated that the factors may be compromised and not entirely applicable to all soil types and weather conditions. Mathematical models were developed to predict growth and yield of oil palm under different environmental conditions. Among these, OPSIM (Oil Palm Simulator) was the first semi-mechanistic oil palm model developed in 1985 (van Kraalingen, 1985 ) with many more developed by Henson in 1989 , 2000, 2009 were among the models that predicts oil palm growth and yield models using meteorological, photosynthesis, rainfall and other crucial factors that may play a role in the growth and yield projection. Adding on to these models, PySawit, a new oil palm growth and yield model was developed by Teh and Cheah (2018) comprising five core components: 1) meteorology, 2) photosynthesis, 3) energy balance, 4) soil water, and 5) crop growth. The model successfully predicts for crop production in the category of level 2; whereby oil palm growth is limited by weather conditions and water. The model also differs from other models as the photosynthesis measurement was carried out using rigorous biochemical measurement of photosynthesis instead of the conventional oil palm radiation use efficiency. Additionally, the model was also able to predict for a wide range of planting density ranging from 120300 palms ha $^{-1}$.

The rapid expansion in oil palm cultivation in Malaysia from its humble beginning of 3000 ha in 1919 to 5.8 million hectares by 2017 brought in unprecedented socio-economic development in the country (Kushairi et al., 2018). Ironically, one of the most important components of agriculture development, mechanisation has been progressing in the same field for the past 100 years (Onwude et al., 2018). Mechanisation has been proven to hold an integral role in almost all aspects of the crop; cultivation, harvesting, storage, transportation (upstream) and finally in the processing (midstream and downstream) of the oil along with other valueadded products derived from the oil. Therefore, taking into consideration of the progress made in other aspects of the crop's development, mechanisation in the upstream which includes operations such as pruning, harvesting of FFB, collection of FFB and loose fruit and finally transportation of FFB and loose fruits to palm oil 
mill for processing (Rafea et al., 2018) has been rather dawdling. Aside from the pressure to remain sustainable, the industry has been continuously introducing changes with mechanised agricultural practices in the field to increase crop yields, efficiency and production. The year 2018 has two improved mechanisation tools refining the existing harvesting tool and the collection of loose fruit namely Cantas Evo and Mark III. Cantas Evo is an upgraded version of Cantas $^{\mathrm{TM}}$, a motorised cutter for palms below $5 \mathrm{~m}$. The improved version has significantly lesser vibration and weight by $95 \%$ and $31 \%$ respectively compared to its previous version Cantas $^{T M}$. Additionally, Cantas Evo was found to incur lesser repair cost by $90 \%$, which amounts to almost RM 3000 per machine each year (Jelani et al., 2018). With reduction in weight and vibration, the equipment can now be effectively used for harvesting on palms with a height of $7 \mathrm{~m}$. These improvements were in line with the weaknesses identified in Cantas $^{\mathrm{TM}}$ on its durability and ergonomics since its introduction in 2007 (Jelani et al., 2008). Right from the conception of Cantas ${ }^{T M}$, eight companies were appointed by MPOB to manufacture the unit for local sales; (1) Fancy Power Sdn Bhd, (2) Jariz Technologies Sdn Bhd, (3) NAFAS Jentera Sdn Bhd, (4) Felda Agriculture Services Sdn Bhd, (5) Alpha Centennial Sdn Bhd, (6) SCH Palmtech Sdn Bhd, (7) Husqvarna Malaysia Sdn Bhd, and (8) NS Creative Sdn Bhd. Among the eight companies, Husqvarna Sdn Bhd is the only company that is appointed to take in overseas orders. While Cantas $^{T M}$ has been available since 2007, the sales of the unit have not picked up as expected. An independent survey by Zainon and Nurul (2019) looked into the reluctance of Malaysian planters investing on this automated cutter and whether the after-sale service influenced the technology transfer. The study found from 30 sampled smallholder respondents, there was a lack of empathy from the sales counterparts and this played a crucial role in deciding the purchase of the unit apart from other qualities such as reliability, responsiveness and assurance.

Moving on to loose fruit collection, Mark III was designed according to the principle of cyclonic vacuum in a cone shape barrel that minimises the bruising of the loose fruit collected (Shuib et al., 2018). The technology allows the separation of loose fruits and lighter materials such as debris (dried leaves and soil fragments) into two layers of the vacuum chambers. It was reported that these individual fruits contain high content of oil whereby reports have stated that a mere 20 fruits fallen from each ripen bunch can contribute to a reduction in OER of $0.92 \%, 0.46 \%$ and $0.37 \%$ in oil palm of $1-5$ years, $6-15$ years and above 15 harvesting years respectively (Gan et al., 1995). MPOB, realising the shortfall in mechanisation advances, has taken a bold step by organising an International Competition on Oil Palm
Mechanisation (ICOPM) which is currently into its third year. The competition invites international engineers and innovators to participate with successful candidates being granted funding for their inventions. It is envisaged through ICOPM, international participation will be encouraged in the country's pursuit of reducing manual labour dependency and overall worker safety through improved cost-effective agricultural operations.

Commercial planting of the African oil palm in four continents along the equatorial belt has a made significant downside to its cultivation; pest and diseases. The intensive monoculture planting has made the crop susceptible to a wide range of indigenous pest and diseases and varies according sto the region that it is cultivated (Sundram and Intan, 2017). In Malaysia, significant economic losses are experienced due to the infestation by two important insect pests namely; bagworm (Metisa plana and Pteroma pendula) and Oryctes rhinoceros beetle (Nurulhidayah and Norman, 2016). However, a recent report by the Department of Agriculture (DOA) (2016) highlighted Rhynchophorus ferrugineus as a potential threat to oil palm. The red palm weevil is a well-known pest of coconut and has been severely infesting on local coconut palms along the east coast of Peninsular Malaysia for more than 10 years (Azmi et al., 2017). With increasing epidemics reported on coconut locations neighbouring oil palm plantations, a dietary investigation was carried out by Ainatun et al. (2018). The study revealed that the weevils preferred oil palm cabbage as opposed to coconut and sago cabbages indicated by the shortest larval stage which now exponentially increases the threat posed by the pest. Two publications in 2018 have highlighted some crucial information that could be relevant in the research of this weevil in Malaysia. The publications highlighted potential control method on the pest using natural biocontrol agent, Beauveria bassiana and the modification on conventional trapping systems whereby the latter described co-attractants using molasses and paraffinic oil increased the capture of the weevils by 3.5-fold (Dembilio et al., 2018; Navarro-Llopis et al., 2018). On a different note, publication by Manley et al. (2018) emphasised on the significant differences on behavioural and oviposition between the wildcaught and laboratory-reared coconut rhinoceros beetles. The study went on to claim as the first to examine the differences and these results were found to aid in the identification sites for management and eradication efforts of the pest. The study clearly suggests that there is discrepancy in results between the biological samples, therefore this warrants a careful assessment before any recommendations were made on the management of insect pest.

One of the key components of agriculture is the management of disease-free cultivation of commercial crops. With the oil palm industry going 
into its fourth generation planting, it is currently seeing the effects of disease devastation; Ganoderma basal stem rot (BSR) infection in terms of economic significance. The research progress on the disease can be categorised into three different research areas; (1) fundamental, (2) detection and (3) management. Each research area will be discussed separately. Biotechnology advancement in the field of genetic has been the greatest in the last decade and powerful tools such as bioinformatics are able to assist in the understanding of host-pathogen interactions. Method development improvement in molecular protocols such as the work by Nagappan et al. (2018) are among the essential protocols in the study of pathogen systematics while Isaac et al. (2018) and Utomo et al. (2018) claimed their first transcriptomic database and draft genome sequence of Ganoderma boninense. It is envisaged that with the generation of big data, development of biomarkers/biosensors for the early detection of the disease will be possible along with other fundamental information in the host-pathogen interaction elucidated (Sulaiman et al., 2018). Through a salinity stress assay, the mycelia growth of $G$. boninense was retarded at mild salinity and totally stopped at a high concentration of $\mathrm{NaCl}$ (Lim et al., 2018a). This corresponded with the increasing expression of GbHOG1 MAPK when the fungus is exposed to $0.4 \mathrm{M} \mathrm{NaCl}$ over a $2 \mathrm{hr}$ period. However, at a higher concentration of $0.8 \mathrm{M} \mathrm{NaCl}$, expression was low as growth of $G$. boninense was affected. The fungal HOG1 MAPK gene plays an essential role in responding to osmotic and oxidative stresses as well as required for mating, growth and the pathogenic process. This study could potentially provide early clues on the involvement of GbHOG1 MAPK in fungal pathogenicity. Finally, on the epidemiology front, Pilotti et al. (2018) revealed that basidiospore (dikaryon) colonisation in roots remains as one of the biggest sources of inoculum and infection in oil palm contrary to the popular belief that root-to-root contact is the main infection source and spread of the disease.

One of the main constraints in managing Ganoderma BSR disease is the difficulty in detecting the disease earlier. Taking into consideration that oil palm is a perennial crop with a life span of 25 years, therefore any manifestation of disease should be detected early enough to save the palm. Although the current work is still very preliminary, potential markers were identified from a molecular assessment that found the infection process of $G$. boninense switches from a biotrophic to necrotrophic phase (Bahari et al., 2018). These highly expressed transcription factors of potential regulators in necrotrophic defense can serve as phase specific biomarkers at the early stages of oil palm - G. boninense interaction. Another molecular-based detection that uses the principle of loop mediated isothermal amplification or more commonly referred as LAMP was developed and preliminary results found the detection was 10-fold more sensitive than conventional polymerase chain reaction (PCR) detection. Another added specificity of this detection is the fact that it uses six primer mixtures as compared to the single primer pair detection in PCR (Madihah et al., 2018). Moving on to non-destructive technologies such as precision agriculture using airborne hyperspectral remote sensing technology has shown some potential in classifying the different stages of Ganoderma infection in mature palms (Izzuddin et al., 2018). The use of continuum removal (CR) was found to be the best parameter in the early detection. Dielectric spectroscopy, a relatively cheaper tool compared to airborne hyperspectral imaging emerged as a promising tool in disease detection. Khaled et al. (2018) demonstrated dielectric property namely impedance (spectral data) as the best parameter in assessing severity of Ganoderma BSR with an overall accuracy ranging from $81.82 \%-100 \%$. This seem like a promising tool to be explored further.

Management of Ganoderma BSR has been mainly driven by cultural practices that reduces the inoculum pressure for a delayed field infection. However, the pressure for a green sustainable technology has increased publications focusing on biocontrol agents and its by-products. Famously known as an aggressive mycoparasite against a wide range of pathogens, Trichoderma has been previously reported as a potential biocontrol agent (BCA) against Ganoderma by Sundram et al. (2008) and Sundram (2013a, b). The studies conducted earlier focused on basic mycoparasitism and efficacy of the BCA as in vivo application with limited work on the mechanism. Therefore, the subsequent studies elucidated the role of Trichoderma in triggering induced systemic resistance (ISR) in infected oil palm seedlings (Habu et al., 2018) while Angel et al. (2018) identified the potential metabolites responsible for the suppression using gas chromatography-mass spectrometry. Apart from Trichoderma, seven hymenomycetes were proven to be prospective candidates of BCA with pathogenicity of these candidates were proven negative on oil palm seedlings (Naidu et al., 2018). These hymenomycetes are capable biodegraders in the field and should be explored further. Alternatively, the use of biofungicides is gaining popularity due to sustainability and in the continuous effort of reducing use of synthetic fungicide. One such study looked into the bacterial anti-fungal cyclic lipopeptides (ACL) synthesised by Bacillus methylotrohicus. The bacterial culture produced three families of ACL namely iturin, surfactin and fengycin with strong anti-fungal activity against Ganoderma (Pramudito et al., 2018). Similarly, Lee et al. (2018a) characterised phenazine and phenazine-1-carboxylic acid isolated from Pseudomonas aeuruginosa with anti-microbial 
activity against $G$. boninense. Another interesting study conducted by Surendran et al. (2018a, b) reported that naturally occurring phenolics acids such as benzoic acid and salicylic acids were able to suppress the enzymatic secretion of Ganoderma spp. and subsequently demonstrated the triggering of ISR enzymes (phenylammonia lyase, peroxidase, polyphenol oxidase) in infected oil palm seedlings. It may seem that much work has been conducted using BCA and its by-products but it needs to be strongly emphasised that these studies still need to be conducted under field conditions to substantiate results obtained under controlled environment.

\section{Advancing with Biotechnology}

One of the major challenges faced by research and development in the upstream sector is to meet the demands of stakeholders for new improved breeding materials. Despite the fact that oil palm breeding can achieve a 1\%-1.5\% yield improvement per year similar to other major crops (Turnbull et al., 2017), the introduction of a new variety following a traditional breeding regime can take 20-40 years, depending on the starting genetic base. This is indeed a grossly inefficient approach if the industry is expected to keep up with the rapidly changing economic and environmental scene (Soh, 2018). More recently, the situation was further aggravated by EU proposing to adopt the Delegated Act which pertains to renewable energy, which simply classifies palm oil unsustainable. As a mitigation measure towards this action, the Malaysian government proposed a cap on Malaysia's palm oil estate at 6.5 million hectares, implying an allowable expansion of a mere 2.5\% annually up to 2023 . This certainly puts further pressure on the need to increase overall oil palm productivity. Typically, agriculture development in the tropics falls behind its temperate counterpart due to lack of technology advancement and other various abiotic and biotic factors (Thottathil et al., 2016). However, in order to meet the increasing demand for food and other plant-based products, improving crop varieties is inevitable. This requires a good understanding of crop genetics. We now know that knowledge extracted from genomes, transcriptomes, expression studies and epigenetics are enablers towards crop improvement. In this respect, the earlier publications of the genome (Singh et al., 2013a, b) and epigenome (Ong-Abdullah et al., 2015) have continued to fuel further research in oil palm.

Bai et al. (2018a) developed genome-wide single nucleotide polymorphisms (SNP) and constructed an ultrahigh-density linkage map using the revolutionary restriction-site associated DNA sequencing (RAD-seq) technology. This technology allowed higher frequency of SNP discovery of at least more than 10000 as compared to the 2000 to
3500 SNP from previous studies (Pootakham et al., 2015; Bai et al., 2017), was modified for use on a highly heterogenous oil palm breeding population. The significant jump in SNP discovered could be attributed to the selection of restriction enzyme, library preparation methods, sequence coverage and heterozygosity of the population used. In addition, the 5727 SNP located in the genic region could facilitate the identification of causative SNP within quantitative trait locus (QTL) for important traits. This linkage map boasts of the highest marker density published to date for the oil palm.

The same group of researchers, possibly an earlier publication to the above, used similar technology to specifically identify the QTL for leaf area (Bai et al., 2018b). The basis of this research stems from the fact that leaves are the key site for photosynthetic activity of the plant which ultimately contributes to crop yield. In associating the genotype information to the phenotype data collected over five years, Bai et al. (2018b) was able to target the gene ARC5 (Gao et al., 2003), located in the QTL region on Chr 9. The ARC5 gene, a cytosolic dynamin-like protein involved in the accumulation and replication of chloroplast 5, was found to be expressed significantly higher in leaf than in root and fruit. This supports the potential of ARC5 as a candidate gene for leaf growth and development. However, its functionality needs to be verified. Nonetheless, the discovery of ARC5 has the potential to be developed as a resource for marker assisted selection for oil palm yield improvement.

Besides efficiency in photosynthetic capacity, yield can also be directly gauged by an increase in the percentage of mesocarp-to-fruit. The two yield related components studied by Ting et al. (2018) were mean fruit weight (MFW) and mean mesocarp weight (MPW). The QTL associated to these bunch component traits were derived from a genetic map of a commercial breeding cross (Deli dura x Yangambi pisifera). Interestingly, the QTL interval mapped revealed 14 candidate genes and transcription factors (TF) related to plant architecture, photosynthesis, nitrogen metabolism, lipid transportation and metabolism, stress response, flowering and formation of stamen and microtubule. Some of these potential genes play key roles in fruit formation that are associated to yield traits in oil palm.

Generally, most oil palm studies have been concentrating on mapping QTL for yield related traits. However, an effective way to increase oil production is to locate oil biosynthesis related genes which can eventually be used in a similar manner as markers for breeding selection (Zhang et al., 2018). Two candidate genes, namely EgGDSL and EgPPR, were studied based on their differential effect on oil biosynthesis. The former had an increased total 
fatty acid content when ectopically expressed in Arabidopsis, whilst no significant difference was detected in the latter when both were compared to wild-type Arabidopsis. In addition, oil palms with higher oil content based on its oil-to-dry mesocarp $(\mathrm{O} / \mathrm{DM})$ content had higher expression of EgGDSL inferring that this gene is likely linked to oil accumulation and may be useful for marker-assisted breeding and in engineering fatty acid metabolism for crop improvement. It is interesting to note that Zheng et al. (2018) chose to employ small noncoding RNA sequencing to analyse lipid and fatty acid metabolism regulatory network in oil palm mesocarp at the genome wide level. This allows the exploration of the interactive relationship between coding and non-coding ribonucleic acid (RNA) involved in fatty acid regulation thus, giving it a new perspective in understanding the mechanism and in enhancing strategies involved in metabolic engineering of oil synthesis in oil palm.

Alternative to physically identifying genes related to traits, in silico analysis offers the alternative for discovery. The rapid evolution of computation biology in tandem with advancements in genome research provides the platform to harness the power of data. Rosli et al. (2018a) utilised comparative genomics analysis to identify orthologous genes from oilseed crops and that of model systems such as Arabidopsis and maize. The analysis resulted in the identification of potential fatty acid biosynthetic genes that are involved in improving the edible oil quality of palm oil such as that of stearoyl-ACP desaturases and thioesterases which control the desaturation of stearic acid and the accumulation of C16 and C18 in mesocarp storage lipids (Parveez et al., 2000). Further to that, the authors have also conducted similar analysis to ascertain candidate $\mathrm{R}$ genes of Elaeis guineensis based on comparison with monocot species, Musa acuminata and Oryza sativa. R genes are important in disease resistance/tolerance as they are early indicators of infection for oil palm diseases such as fusarium wilt, bud rot and BSR. Ultimately, these candidate genes can be exploited as markers for screening breeding populations for fatty acid quality and disease resistance/tolerance, respectively.

On 4 October 2018, Bloomberg Business featured an article entitled, New Dwarf Trees Set to Revolutionise the Palm Oil Market (Raghu, 2018). This was a follow up article on the introduction of MPOB's Clonal Palm Series (CPS) 2 which highlights distinct morphological traits such as slow height increment and short frond length compared to the current standard planting materials (Figure 1). Data has also shown that due to its unique characteristics, CPS2 can be planted at a higher density, close to 200 palms ha $^{-1}$ (Rosli et al., 2018b). High density planting has been proven to boost yields per unit area (Majid et al., 2018; Dalvi et al., 2010) and with the added slow growth, CPS2 is poised to become the next generation planting material.

The application of beneficial microbes is a vital alternative to chemical fertilisers and pesticides. In promotingsustainableagricultureandenvironmental well-being, microbial technology and its applications are becoming more important (Bhattacharyya et al., 2016). Lim et al. (2018b) introduced the application of diazotrophic rhizobacteria, a plant growth enhancer, on micropropagated oil palms. Tissue culture derived plantlets are said to be naturally more fragile with frangible roots that are inefficient in water and nutrient absorption. In the presence of Herbaspirillum seropedicae (Z78), a nitrogen-fixing and phytohormone-producing bacterium, phytohormone indole-3-acetic acid (IAA) production is enhanced for better root growth leading to a boost in the general health of the palms.

As the acceptance of utilising tissue culturederived oil palms grows, research into improving the cloning process continues to generate new knowledge. Lee et al. (2018b) isolated the oil palm homologue of Somatic Embryogenesis Receptor Kinase (SERK) 1 gene which confers embryogenic competence to somatic cells. Their findings suggest that this gene is more involved in the callogenesis process per se. Subsequent to that, Aroonluk et al. (2018) focussed on characterising differentially expressed glycoproteins during somatic embryogenesis using a specific affinity column in the hope of developing glycoprotein biomarkers for somatic embryo maturation. The abnormal mantled phenotype of oil palm which generally arises from tissue culture was studied at a finer detail by Ooi et al. (2018). Transcriptomes were carried out on laser capture microdissected male and female organs from both normal and mantled female inflorescences. The feminisation of male staminodes into pseudocarpels in pistillated inflorescences involved a reduction in the expression of Heat Shock Protein (HSP) genes and floral regulatory genes such as EgDEF1 and $E g G L O 1$, but with the exception of LEAFY that had an increased expression. Ong-Abdullah et al. (2015) has shown that in deciphering clonal behaviour, it is essential to understand the epigenetic mechanisms involved. Sarpan et al. (2018) reported on an optimised Chromatin Immunoprecipitation (ChIP) protocol to efficiently study histone modifications in oil palm.

Proteins are gene products that can directly correspond with phenotypic traits. In this respect, Lau et al. (2018a) gave a comprehensive account of proteomics as an emerging technology to link the genome-wide transcriptomics and metabolomicsbased studies for oil palm crop improvement. It is also noteworthy to mention that there is a growing number of publications on Elaies oleifera as it is an important source of genetic variability and a promising resource for oil palm breeding 
programmes (Montúfar et al., 2018). Efforts to clone and in understanding the somatic embryogenesis mechanism in E. oleifera (Ahmad Tarmizi Hashim, pers. comm., 2018) and its interspecific hybrid (Santos et al., 2018) are underway. In an unrelated study, transcriptome profiling of pollens from dura, pisifera and tenera of E. guineensis was performed to understand the molecular mechanism related to pollen germination. It was found that tenera and pisifera share rather significant similarities between them which could infer that the regulation of pollen germination in tenera and pisifera may be genetically identical (Wang et al., 2018a, b).

The modification of fatty acid composition and synthesis of high value metabolites are main targets set for the genetic engineering programme for oil palm (Parveez et al., 2000). In realising this endeavour, it is important that the final product(s) are targeted at the right tissue(s). Therefore, this would require the isolation and determination of tissue specific or constitutive promoters. Zubaidah et al. (2018) provided a comprehensive review on the progress of tissue-specific and constitutive promoters sourced from the oil palm. Selection of true and stable transformants has been challenging for oil palm genetic engineering on a whole. The use of the green fluorescent protein gene $(g f p)$ as a selectable marker for oil palm was attempted (Parveez and Majid, 2018), however it did not result in the regeneration of any stable transformants. In 2015, although Parveez et al. successfully synthesised polyhydroxybutyrate (PHB), a form of biodegradable plastic, albeit in a small amount in the oil palm, its true integration was never verified until recently. Madon et al. (2018) using fluorescence in situ hybridisation, flow cytometry and cytological techniques demonstrated positive integration of PHB genes in transgenic oil palm plantlets. This is

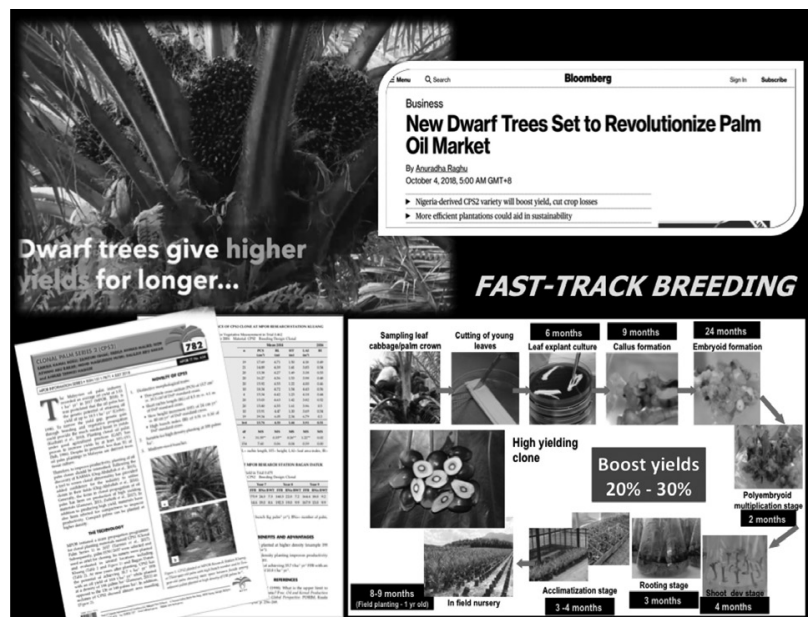

Figure 1. MPOB's Tissue Culture Programme was initiated as a strategy to fast-track breeding. Clonal Palm Series (CPS2) was introduced to the industry at the Transfer of Technology Seminar 2018 in July and followed by an online article by Bloomberg. indeed a first report on transgene detection in oil palm using the cytological approach.

An interesting review by Paterson and Lima (2018) implied that tropical countries in general are going to feel the brunt of climate change and situation will get worse for oil palm come 2100 (Paterson et al., $2015 ; 2017)$. Loss of yields are projected at $30 \%$ with an increase in temperature by $2^{\circ} \mathrm{C}$ above optimum and a decrease in rainfall by $10 \%$ (Paterson and Lima, 2018). Furthermore, oil palms are generally susceptible to drought (Dislich et al., 2017). Climate change also alters soil factors which could lead to restricted root growth causing nutrient stress to occur (Brouder and Volenec, 2008). In view of these concerns, breeding for drought tolerance in oil palm has become increasingly important. Corley et al. (2018) based their estimation of drought tolerance in oil palm on the reduction of yield caused by withholding irrigation. In a separate study, Oettli et al. (2018) successfully constructed a stable and reliable linear model that is able to predict total FFB yields. The model was based on data combining the effect of local climate with the larger scale climate modes such as the $\mathrm{El} \mathrm{Nino/Southern} \mathrm{Oscillation}$ (ENSO).

The limited knowledge of the molecular mechanisms of nutrient acquisition in plants, motivated Husri and Ong-Abdullah (2018) to study potassium $\left(\mathrm{K}^{+}\right)$transporters in oil palm. As $\mathrm{K}^{+}$is one of the most important elements in fertilisation with a direct effect on yields, oil palm with an efficient transporter system is one that is sensitive to changes in the external $\mathrm{K}^{+}$concentration. Although, none of the EgKUP3, EgKUP8 and EgKUP11 genes isolated fulfilled the criteria of a high-affinity transporter, the transcriptionally activated EgKUP8 in a deficient $\mathrm{K}^{+}$environment could be compensated by its low efficiency. Alternatively, the impact of climate change could be offset through genetic engineering (Masani et al., 2018; Murphy, 2018). Despite the current negative perception towards genetically modified organisms (GMO), the advent of gene editing technology which is more precise, costeffective and does not involve the introduction of foreign genes, could generally allay some of the concerns.

\section{Empowering Smallholders}

Continuous training and extension programmes are important for smallholders to enhance their knowledge and skills in oil palm management practices. An evaluation study was conducted to determine the relationship between attitude of trainees towards training and training effectiveness. Study by Zulkifli et al. (2018a) found that trainee's attitude conceptualised in terms of experience, social status and perceived training benefits has a significant influence on training effectiveness. The 
study recommended that special attention should be given by the trainers on the elements of social support and perceived training benefits. Good communication systems and effective interaction between both smallholders and training providers will ensure that farmers are well informed and are able to select the appropriate programmes that best fit their requirements. Therefore, designing the course content is a crucial part of training for smallholders, so that the programmes will achieve the expected objectives.

Currently, the Malaysian government via various agencies are exploring methods to entice the younger generation towards entrepreneurship, especially in the agribusiness sector. Oil palm, as one of the key agricultural sectors has the potential to provide opportunities for young entrepreneurs to dabble in agribusiness. However, these prospects may be overlooked, therefore efforts are undertaken to encourage graduates to become modern agribusiness entrepreneurs and simultaneously, projecting themselves as role model to their peers to participate in oil palm entrepreneurship. Dynamic involvement of this group will reduce the rate of unemployment and raise the status of the agriculture sector. Based on the study by Zaki et al. (2018), the key factor influencing the choice of career in the agricultural sector is job security. The social status of the students was not the determining cause for their involvement in agribusiness entrepreneurship. It is important that the relevant government authorities design and develop appropriate programmes and activities to boost the interest of the younger generation towards becoming agribusiness entrepreneurs.

The Malaysia government has introduced various programmes to enhance the oil palm productivity and sustainability through the implementation of Good Agricultural Practices (GAP) among oil palm smallholders. Awang et al. (2018) reported that smallholders have the capabilities to understand the value and importance of adopting innovative technologies provided they are given proper guidance from the extension agents. These extension agents are responsible in conveying or delivering the knowledge to the smallholders regardless of their educational background, ethnicity, culture or religious beliefs. Throughout the whole process, feedback from the smallholders on the effectiveness of the extension agents in carrying out the task are being recorded and measures are also taken to address pertinent issues raised by this group with regards to the implementation of GAP along with the newly introduced technologies.

In 2010, Sustainable Palm Oil Clusters (SPOC) was initiated to safeguard the competitiveness of the smallholder sector. The main objective of SPOC is to improve the productivity and quality of FFB through certification and to increase the income of independent smallholders via the establishment of the Sustainable Oil Palm Growers Cooperatives (KPSM). Besides low FFB yield, poor returns on OER by the dealers and mills are issues faced by these independent smallholders. It was claimed that buyers or millers are not paying the equivalent value of OER with quality of FFB sold, thus affecting smallholders' earnings. Based on the study conducted in July 2012 by Azman and Nazirah (2018) on the impact of the establishment of KPSM on smallholder income in Malaysia, it was found that the nett average FFB price after deducting transportation cost obtained by cooperative members was higher than for non-members. The average nett price obtained by KPSM members was RM 524.80 (USD 127.52) per tonne, compared to only RM 414.60 (USD 100.75) per tonne obtained by non-members with a price difference of RM 110.20 (USD 24.59) per tonne. This goes to show that selling FFB to cooperatives may be an alternative for independent smallholders to get better income.

Labour shortage has been a long-standing issue that plagued the oil palm industry both large estates and smallholders. Oil palm industry is labourintensive, where core activities such as harvesting and FFB collection still require a high number of labour compared to other field activities. This shortage has seriously impacted the daily operations at the oil palm plantations. Azman et al. (2018a) conducted a study on labour requirement targeting two main activities, harvesting and FFB collection in Sabah and Sarawak. The labour requirement in Sabah and Sarawak were estimated at 7837 and 4807 workers, with the land-labour ratio for harvesting and FFB collection in Sabah and Sarawak at 1.35:1 and 1.41:1, respectively. While the study by Azman et al. (2018b) on independent smallholders in Peninsular Malaysia indicated that for harvesting and FFB collection, the total labour required was estimated at 25014 people at a shortage of 3715 workers. In Peninsular Malaysia the land-labour ratio for harvesting and FFB collection was one worker for every 1.5 ha of planted area.

Among the main factors causing low productivity in the smallholder sector are aged oil palm that are unproductive or the planting of lowquality seedlings. Realising the importance of these independent oil palm smallholders in Malaysia, the government through MPOB has introduced the Replanting and New Planting Assistance Scheme for the independent oil palm smallholders. The scheme basically provides funds with the value not exceeding RM 7500 (USD 1822.46) per hectare for Peninsular Malaysia and RM 9000 (USD 2186.95) per hectare for Sabah and Sarawak to incentivize replanting. Eligible smallholders were provided with cash incentive for land preparations prior to planting, supply of high-quality oil palm seedlings, and provision for fertiliser for the first and second 
year of planting inclusive of chemical inputs for controlling pests such as weeds, insects or diseases. As reported by Zulkifli et al. (2018b), replantings carried out in 2011 and 2012 have successfully reaped the benefits of replacing the unproductive oil palms with an additional income of RM 100 (USD 24.3) per month. Meanwhile, participants involved in the new planting assistance scheme have also gained extra income of about RM 800 (USD 194.4) per month. However, the income is subjected to the current price of oil palm. Study by Zulkifli et al. (2018b) also showed that most participants readily embraced GAP after joining the assistance scheme.

\section{Innovations in the Milling Sector}

Research has been conducted on different treatment methods on palm oil mill effluent (POME) other than the historical anaerobic digestion. Among them are ozonation aided mesophilic treatment that produces bio-hydrogen from POME. The highest chemical oxygen demand (COD) removal from this process was only at $44 \%$ but had a hydrogen production rate of $43.1 \mathrm{ml} \mathrm{hr}^{-1}$ (Tanikkul et al., 2018). This study showed that the ozonisation process can be carried out as a pre-treatment on POME before subsequent treatment because this step can produce good rates of bio-hydrogen (Tanikkul et al., 2018). Another treatment approach for POME conducted by $\mathrm{Ng}$ et al. (2018) used the cataly tic steaming process that produced syngas. A $93.7 \%$ reduction in COD and $93.8 \%$ reduction in biological oxygen demand (BOD) was achieved in the presence of catalyst and liquid-hourly-space-velocity in POME. The gas phase had $\mathrm{H}_{2}$ as the major component followed by $\mathrm{CO}_{2}, \mathrm{CO}$ and $\mathrm{CH}_{4}(\mathrm{Ng}$ et al., 2018).

Treatment of the final discharge of POME using activated bio-adsorbent from oil palm kernel shell was conducted by Zainal et al. (2018) which reduced the total suspended solids by $90 \%$, the COD by $68 \%$, colour by $97 \%$ and BOD up to $83 \%$. This process can aid the palm oil mills in meeting the regulation limits set by the Department of Environment. POME was also evaluated as a carbon source for microalgae growth (Idris et al., 2018). The benefit from doing this is that the POME gets treated and the cost of algae cultivation is reduced. The study showed that cultivation of algae in POME has managed to reduce the $\mathrm{PO}_{4^{\prime}} \mathrm{NO}_{3^{\prime}}, \mathrm{NO}_{2}$ and the COD in POME. Based on the fatty acid profile, the POME cultivated microalgae also showed good potential to be used as biodiesel (Idris et al., 2018).

Research has also been conducted to exploit POME as a raw material to obtain hydrogen and methane, due to the presence of carbohydrates, lipids and proteins which can be metabolised during the dark fermentation process (Alessandro et al., 2018). Extraction of hydrogen has a potential to be used in various industries, such as the chemical, biochemical and food industries and the methane which is combustible can be used for energy (Alessandro et al., 2018).

The most renowned way to overcome biogas emissions from the anaerobic treatment of POME was through biogas capture and extensive studies were conducted previously on the technologies, feasibility and greenhouse gas (GHG) emissions savings by capturing this biogas. The research in biogas capture from POME is now mostly focused on improving the production of biogas. According to Choong et al. (2018) since anaerobic digestion is dependent on the microbial biological process; the condition of the feedstock (POME) that comes into the digestor system needs to be conducive for these microbes to live and metabolise. The operation temperature, volume as well as improvement on co-digestion and retention of biomass within the digestor is of utmost importance. The recommended practices to achieve these were thorough pre-treatment of the POME and also applying additives (Choong et al., 2018). The study also suggested to modify the bioreactor to obtain more conducive conditions. Even though these strategies were found to increase the production of biogas the study concluded that these practices could not be compared with each other to obtain the best practice as the operating conditions for each of these practices were different (Choong et al., 2018). Treatment of POME is more of an end of pipe solution where the upstream milling process can be improved to subsequently reduce the amount of POME discharged.

\section{Biomass and Bioenergy}

Malaysia has a plethora of biomass mainly from the oil palm industry. At the $15^{\text {th }}$ Conference of Parties in Copenhagen, Denmark, Malaysia pledged to voluntarily reduce its emissions intensity of gross domestic products by $40 \%$ by 2020 from 2005 levels. It is envisaged that the utilisation of these biomass as bioenergy will help the nation move towards this goal (Sadhukhan et al., 2018). This brought about many researches on the treatment and conversion of biomass to become a source of bioenergy. Pyrolysis is one of the more popular processes to produce biooils from biomass. Qureshi et al. (2018) compared a new semi-continuous pyrolysis method with the historical batch pyrolysis process which tends to involve high residence time, product inconsistency, difficulty in scaling up, etc. The study found the continuous system to be superior due to its ability for in situ withdrawals. However, concluded that to design a better and more efficient continuous pyrolysis system all pros and cons of both systems need to be taken into consideration (Qureshi et al., 2018). A review on the bio-oils derived from the empty fruit bunches (EFB) using fast pyrolysis and 
liquefaction processes was conducted by Chang (2018). The study basically compared the physicochemical properties of the EFB-derived bio-oils with bio-oils from other biomass as well as petroleum fuel oils. The bio-oils derived through fast pyrolysis from EFB had a lower sulphur content, $\mathrm{pH}$ and heating value but higher ash, solid content, density and total acid number as compared to petroleum fuel oil (Chang, 2018). This makes the bio-oils more acidic, susceptible to carbon deposit formation and more corrosive than petroleum fuel oil. However, the bio-oils emit less sulphur oxides during combustion. Even though bio-oils have undergone some upgrades, the methods used pose numerous drawbacks. The deficiencies in bio-oils resulted in their restricted application in replacing heating oils and diesel fuels. It was concluded that the various limitations in fuel application of EFB-derived biooils need to be solved to enable this field to progress (Chang, 2018).

Using the same fast pyrolysis method with a fluidised bed reactor, Sukiran et al. (2018) converted EFB into bio-oils and bio-char. The study explored three types of pre-treatments, which were washing with $\mathrm{H}_{2} \mathrm{SO}_{4^{\prime}} \mathrm{NaOH}$ and distilled water. The first method with $\mathrm{H}_{2} \mathrm{SO}_{4}$ gave the highest bio-oil yield at $55.6 \mathrm{wt} \%$ and reduction in ash content by $56 \%$. The washed bio-oil and bio-char with lower ash had similar fuel characteristics with those from the unwashed feedstocks (Sukiran et al., 2018). Chan et al. (2018a) used the supercritical carbon dioxide to extract bio-oils from palm kernel shell (PKS) and examined the solubility of bio-oils and phenol at various temperatures and pressures. The bio-oil solubility generally increased with temperature and pressure, also due to increased vapour pressure of solute, as well as enhanced density of solvent. The highest solubility of bio-oil at $1.0393 \times 10^{-3}$ $\mathrm{g} \mathrm{g}^{-1} \mathrm{CO}_{2^{\prime}}$, was obtained at $70^{\circ} \mathrm{C}$ and $40 \mathrm{MPa}$. The enrichment of phenol in the bio-oil extract suggests that supercritical carbon dioxide could be a feasible option for fractionation of raw bio-oil to recover useful bio-chemicals (Chan et al., 2018a).

Other than bio-oils, EFB can also be converted to ethanol. A study to optimise the fermentation process in the conversion of EFB to bioethanol via response surface methodology was conducted by Loh et al. (2018). The optimised conditions of $\mathrm{pH} 4$, $30^{\circ} \mathrm{C}$ and $150 \mathrm{rpm}$ at $72 \mathrm{hr}$ batch fermentation gave a maximum bioethanol yield of $0.66 \mathrm{~g} \mathrm{~g}^{-1}$ glucose. The results showed that the optimisation was reliable (Loh et al., 2018).

Research by Lau et al. (2018b) showed that oil palm fronds that are torrefied at $250^{\circ} \mathrm{C}$ gives the oil palm fronds a higher heating value making them highly suitable to be co-fired with coal at the coal power plants for bio-energy. Solid biofuels derived from lignocellulosic biomass often exhibit ash related problems during their combustion.
An analysis was carried out by Chin et al. (2018) on introducing fuel additives such as kaolin and calcite to examine the ash melting characteristics as well as the heating values of oil palm biomass specifically for EFB and oil palm trunk. Kaolin reduces the sintering degree of ashes while calcite increases the melting temperature, however this induces high concentration of fly ash in the flue gas. As a conclusion, the study found kaolin to be more efficient as fuel additive compared to calcite in tackling the ash problem (Chin et al., 2018).

In addressing the lignin within the biomass which is a renewable bio-resource, a study to extract this hydrocarbon from EFB, pressed mesocarp fibre (PMF) and PKS was carried out using pyridium formate (a protic ionic liquid) under mild extraction conditions (Rashid et al., 2018). The lignin saturation concentration obtained were very close to its theoretical values. Even the processing temperature was much lower as compared to other reported temperature used for lignin extraction making this process better than the conventional chemical process (Rashid et al., 2018). Pre-treatment of lignocellulosic biomass is divided into physical, chemical, physico-chemical and biological with each having their own pros and cons and cannot be used for all types of biomass. The review by Kumari and Singh (2018) showed that combining two or more pre-treatments resulted in improved yields but was more energy intensive (Kumari and Singh, 2018). Currently, more research is needed to develop better methods and technologies for the pre-treatment of lignocellulosic biomass before second generation biofuels from biomass can be truly exploited.

\section{Addressing Environmental Nuances}

The oil palm industry is constantly being scrutinised on its environmental performance. The indirect land use change (ILUC) issue resurfaced in 2018 after years of debate at EU regarding the inclusion of ILUC in the revision and update of its Renewable Energy Sources Directive, referred to as the RED II. The RED II does not yet include an express 'ban' of palm oil-based biofuels. Rather, it hides the potential 'ban' of palm oil-based biofuels behind rules that will apply to all biofuel crops. More specifically, Article 26(2) of the RED II on 'Specific rules for biofuels, bioliquids and biomass fuels produced from food and feed crops' calls for the determination of 'low indirect land use changerisk biofuels.

The biofuels GHG emissions are severely impacted with the inclusion of ILUC (Brinkman et al., 2018). Mitigating ILUC risk is important to avoid additional GHG emissions compared to fossil fuels (Brinkman et al., 2018). However, this should be carried out in a more reliable and scientific way. Generally, many components of the regulations 
are very restrictive to oil palm and prepared and presented without clear scientific evidence. The regulations appear to be targeted at disqualifying the use of palm oil as biofuel, which can be construed as a form of trade protectionism.

On the sustainability certification aspect, Higgins and Richards (2018) discussed that sustainability standards schemes which are initiated through multi-stakeholders will be more effective instead of just an international scheme like Rountable on Sustainable Palm Oil (RSPO) which were found to be depoliticising and marginalising. The article discusses that these local multi-stakeholders' certification like the Indonesian and Malaysian Sustainable Palm Oil standards (ISPO and MSPO) are not given enough attention in the literature as well as globally. The study found that schemes like the ISPO and MSPO are crucial as they create an alternative farming frame for smallholders who may not be equipped to participate in RSPO both technically and financially. ISPO and MSPO can also offer a means for the oil palm sector in these regions to still improve their farming in a sustainable way without having to comply to the challenges and demands posed by RSPO (Higgins and Richards, 2018).

White and Knight (2018) reported that more and more palm oil companies have made pledges and commitments to fight and eliminate deforestation within their operations. However, the study identified seven major barriers that are making it very difficult for companies to implement this commitment holistically. Mainly due to the complexities along the oil palm supply chain as well as lack of consensus on the actual definitions of deforestation. Other barriers include lack of government support and also market demands. The study concluded that the existing methods used to combat deforestation by the NGO like shaming campaigns or boycott campaigns will

Direct water consumption $\mathrm{m}^{3} \mathrm{t}^{-1}$ crude palm oil

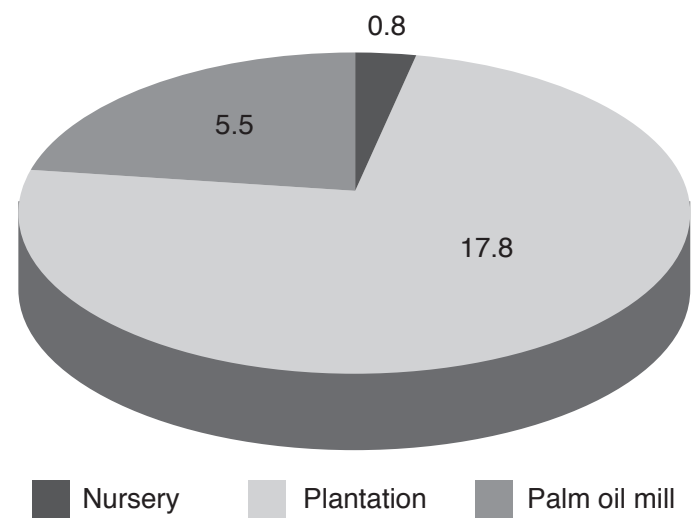

Figure 2. Direct water consumption at the various stages ( $m^{3} t^{-1}$ crude palm oil). not help address the deforestation problems. A larger mechanism has to be put in place that overcomes the identified barriers which the individual companies will not be able to tackle by themselves to move towards no deforestation (White and Knight, 2018).

On a positive note, a water footprint study for the Malaysian oil palm industry was carried by Subramaniam and Hashim (2018) which showed that the impact from the water consumption of the oil palm were minimal. Figure 2 shows the direct water consumption for the various stages from nursery, plantation to the palm oil mill for $1 \mathrm{t}$ of $\mathrm{CPO}$. This amount is then gauged against the water stress index of the region, which was at less than 0.1 , indicating that the region has a high renewable water availability. This resulted in a low direct water footprint for the production of palm oil. This contradicts general perceptions of most agriculture products where the notion to assume that the most significant impact will arise from the use of water at the crop cultivation stage. The study proves that the reason why this happens for the oil palm was mainly due to its non-irrigation practices and the location of Malaysia in a water abundant region. The study showed that planting oil palm at areas with high water availability and low water scarcity index is important (Subramaniam and Hashim, 2018).

An analysis on the different methods and approaches used to carry out 11 life cycle assessment (LCA) studies for palm biodiesel was carried out by Archer et al. (2018). The analysis found that even though all the LCA were carried out according to the ISO 14044 Standards, there seem to be a wide variation in the results. The most significant differences occurred in the inventory data, methodology and use of different self-claimed green technologies. The article suggested interstudy comparison and in-depth research to reduce the variation in the findings (Archer et al., 2018). The Malaysian oil palm industry is definitely moving towards being more and more sustainable and will one day surpass all vegetable oil crops in terms of achieving greater heights through better environmental performance and productivity.

\section{Food Safety and Nutrition}

The continuous monitoring of the food safety and authenticity aspects of palm oil and its products remains one of the main focuses of the oil palm industry in ensuring compliance with the latest international food standards and safety regulations. Pertinent issues related to the traceability, safety and authenticity of palm oil encompasses the industry's efforts in improving the traceability of palm oil throughout their supply chain, development of newer evolving techniques for the 
rapid detection of adulterants and contaminants in palm oil and implementation of food safety and sustainability certifications within the current management systems (Goggin and Murphy, 2018). These steps illustrate the continued commitment of the palm oil industry in adhering to established trading requirements for palm oil that is produced sustainably and responsibly.

\section{Food Safety Issues Related to 3-MCPD and Glycidol Esters}

Over a decade ago, the occurrence of 3-monochloropropane-1,2-diol (3-MCPD) esters and glycidyl fatty acid esters (GE) in palm oil products was first highlighted as palm oil was reported to contain one of the highest levels of these food contaminants amongst all vegetable oils. Since then, these process-induced contaminants have been found to be present in numerous food and ingredients, ranging from refined vegetable oils, sauces, soups to meat products and infant formula and that the development of biomarker exposure monitoring of 3-MCPD esters and GE is ultimately required for assessing human exposure to those process contaminants so as to be better informed of the associated risk assessments (Rietjens et al., 2018). A 2018 update on the European Food Safety Authority (EFSA) report published in 2016 established that the total daily intake (TDI) of $2 \mu \mathrm{g}$ $\mathrm{kg}^{-1}$ body weight per day of 3-MCPD and its fatty acid esters has replaced the earlier TDI of $0.8 \mu \mathrm{g}$ $\mathrm{kg}^{-1}$ body weight. Despite the increase, it has not exceeded the level allowable for adults, however it slightly exceeds the TDI for children fed with commercial infant formulas (Knutsen et al., 2018). The maximum level of GE, a food contaminant concluded to be genotoxic and carcinogenic by EFSA, however, was recently amended to establish a stricter limit particularly in infant formula, followon formula and food for special medical purposes intended for infants and young children (European Commission, 2018). In this recent EU regulation, maximum levels for GE of $1 \mathrm{ppm}$ and $0.5 \mathrm{ppm}$ were established for vegetable oils and fats placed on the market for the final consumer and for use as an ingredient in food and those destined for the production of baby food and processed cereal-based food for infants and young children, respectively.

In the past year, the palm oil industry has continued to strengthen its commitment towards the abatement of 3-MCPD esters and GE during palm oil processing through $R \& D$ intensification on these process-induced food contaminants. In a recent investigation into the possible precursors of 3-MCPD esters in vegetable oils, Tiong et al. (2018) confirmed that diacylglycerol organochlorine compounds, primarily sphingolipid organochlorine compounds formed during oil biosynthesis in fruits were the most active precursors of 3-MCPD esters and suggested more attention was focused into decreasing their formation in the palm fruit or removal during processing. Improvements on the palm oil refining process through the implementation of water degumming was found to significantly reduce 3-MCPD esters by up to $50 \%$ and a high dosage of phosphoric acid combined with acid activated bleaching earth resulted in the complete elimination of GE (Sim et al., 2018). Both of these studies revealed that the initial CPO quality plays a crucial role in the formation of 3-MCPD esters and GE formation in refined palm oil and the amount of minor components such as partial acylglycerols and free fatty acids should be kept at a minimum by shortening the time between harvesting and milling. In another study by Kyselka et al. (2018), through a modified process, wet fractionation of palm oil using acetone was able to significantly decrease 3-MCPD esters and GE in the hard and super stearins by up to $71 \%-74 \%$ and $21 \%-26 \%$, respectively. The study further revealed that rapid degradation of 3-MCPD esters and GE in palm oil could be achieved through exhaustive hydrogenation and the combined usage of $22 \% \mathrm{Ni}$ and Raney nickel catalysts, which transformed the fatty acid esters of glycidol and 3-MCPD into non-carcinogenic and non-genotoxic products by hydrogenolysis and deoxygenation reactions. Recent advances in the analytical methods for the determination of 3-MCPD esters and GE in vegetable oils and various other foodstuff have established direct and indirect approaches using gas chromatography-mass spectrometry (GC-MS) and high performance liquid chromatographymass spectrometry (LC-MS), respectively (Arisseto et al., 2018a). A modified QuEChERS method which includes a partitioned liquid-liquid extraction (PLLE) and dispersive solid phase extraction (dSPE) clean-up step followed by liquid chromatographytandem mass spectrometry (LC-MS/MS) has been reported as a fast and effective method for the determination of 3-MCPD esters in edible oils and margarines (Custodio-Mendoza et al., 2018). The detection of MCPD esters and GE in multiple reaction monitoring (MRM) mode by gas chromatography triple quadrupole spectrometry in a study by Goh et al. (2018) was proven to be robust with higher selectivity and sensitivity at low concentrations of the contaminants compared to the selected ion monitoring (SIM) mode.

Further research efforts investigating the formation of contaminants such as 3-MCPD esters and GE in vegetable oils using different cooking methods have been reported in the past year. In a study by Arisseto et al. (2018b) examining the influence of potato cultivar, frying oil and sample pre-treatments on 3-MCPD esters levels in French fries, they observed that 3-MCPD esters content in French fries was dependent on factors related to 
oil uptake during frying, namely the initial level of 3-MCPD in the frying oil and the frying temperature applied. Selection of potato cultivars with a low moisture content (highest dry matter content) as well as a pre-treatment application of pectin film on blanched samples reduced the 3-MCPD esters levels in the French fries. Several studies have shown that the major contributors of the presence of 3-MCPD esters and GE in food products during frying was the absorption of the frying oil, the frying temperature and heating period (Merkel et al., 2018a, b). Although both studies were not conducted using palm oil, several mitigation strategies to reduce the content of 3-MCPD esters and GE in the food product were recommended through proper oil management practices such as filtering-off solid particles within the oil and the use of absorbent materials such as pulverised zeolite, which could be applied similarly in a palm oil-based frying system. Both studies also suggested analyses of total polar materials and spectrophotometric measurements of colour for the assessment of the frying oils as fast screening methods for estimating 3-MCPD esters content in food matrices.

\section{Recent Evidences on Palm Oil Attributes in Human Health}

In the past year, there was a surge in the amount of studies focused on health and nutritional aspects of consuming palm oil and its effects on the human diet. Despite the widely accepted claim that consuming high amounts of saturated fatty acids and palm oil in particular, contributes to the increased prevalence of cardiovascular diseases worldwide, a recent systematic review by Ismail et al. (2018) revealed no evidence of any clear association between palm oil consumption and the risk and mortality from coronary heart disease and stroke. Another review on the nutritional characteristics and health effects of palm oil use in children also found no evidence to suggest that palm oil negatively affects the health of children to date (Di Genova et al., 2018). Consumption of diets containing repeatedly heated vegetable oils in general was found to increase the risk of cardiovascular disease due to the deterioration of cardiovascular protective benefits of vegetable oils and the generation of volatile and non-volatile degradation products from oxidation, hydrolysis and polymerisation, especially during the deep frying of food (Ganesan et al., 2018). A study on the effect of consuming heated oils with or without dietary cholesterol on atherosclerosis development in a rabbit model by Che Idris et al. (2018) found that the formation of aortic lesions in rabbits fed with corn oil was higher compared to those fed with palm olein. The authors concluded that the atheroprotective effects of palm olein could be attributed to the higher content of vitamin $\mathrm{E}$ which confers the oil antioxidant protection during heat treatments.

The impact of palm oil versus other oils on weight changes was recently systematically reviewed and further indicated that there was insufficient evidence to suggest the association between dietary palm oil intake and obesity (Muhamad et al., 2018). In an in vivo study involving diet-induced obese mice fed with palm olein and palm olein-olive oil blends, Teh et al. (2018a) showed that the mice developed less body fat accumulation compared to those fed with olive oil alone, further supporting the evidence on the similar effects of palm oil and olive oil on lipid profile. A follow-up study on the comparison between the effects of palm-based high oleic blended cooking oil, extra virgin olive oil and coconut oil diets on biomarkers of inflammation, obesity and blood pressure further revealed no significant differences between the three oils on the anthropometric indices, serum biomarkers of obesity, inflammatory biomarkers and blood pressure measurements of the subjects in the study (Lee et al., 2018c). These findings significantly contribute to the growing body of scientific evidence which support and highlight the neutral effects of consuming palm olein in comparison to other vegetable oils on obesity and total serum lipids in healthy individuals.

The misconceptions on the deleterious effects of saturated fats was recently addressed in a comprehensive review by Teh et al. (2018b) and concrete evidence was presented to indicate that the majority of vegetable oils, including palm olein contained more than $89 \%$ of unsaturated fatty acids predominantly at the sn- 2 position and that palm olein exhibited comparable effects on serum cholesterol levels with other vegetable oils such as olive, soyabean, peanut, sunflower seed and canola oils. In a study comparing the effects of palm olein, cocoa butter and extra virgin olive oil (EVOO) on the lipid profile of young, healthy Chinese population, Cheng et al. (2018) found that the three oils exhibited almost identical effects on serum lipids despite palm olein and cocoa butter possessing a higher saturated fatty acids (SFA) content compared to EVOO. In addition, Sun et al. (2018) demonstrated that no significant difference was found between the dietary consumption of palm olein and olive oil on body mass index and serum lipid profiles in a Chinese population. An investigation into the postprandial effects of palm olein and chemically interesterified palm olein with palmitic acid at the sn-2 position at different proportions compared to high oleic sunflower oil as the control fat on gut hormones, glucose homeostasis, satiety, lipid and inflammatory parameters in type 2 diabetic subjects found no adverse effects of interesterification on hormones associated with glucose homeostasis, particularly GLP-1 in the subjects (Mo et al., 2018). 
There continues to be increasing evidence demonstrating the potential health promoting effects of nutraceuticals and phytonutrients derived from palm oil. These nutrients include tocotrienols, phenolics, carotenes, phytosterols and squalene, among others. The effect of red palm olein compared to palm olein consumption on inflammatory and metabolic risk markers in abdominally overweight individuals at risk of developing cardiovascular disease was investigated by Loganathan et al. (2018) and the study reported a significant reduction in the oxidised low density lipoprotein (LDL) levels and increased levels of antioxidants in the subjects which consumed the red palm olein diet. This effect was postulated to be due to the presence of high amounts of phytonutrients which include carotenoids, vitamin E, phytosterols, squalene and co-enzyme Q10 in red palm olein which have previously been shown to possess cardioprotective benefits. The effects of palm tocotrienols on diabetic nephropathy in patients with type 2 diabetes was recently investigated by Tan et al. (2018) and they demonstrated that a twice daily dose of $200 \mathrm{mg}$ of tocotrienol-rich vitamin E supplementation resulted in reduced serum creatinine compared to placebo in the subjects, further suggesting tocotrienols as a useful addition for the treatment of diabetic nephropathy. A comparison on the effects of palm oil tocotrienol-rich fraction (TRF) and $\alpha$-tocopherol supplementation on antioxidant levels of healthy older adults aged between 50 and 55 years found that both supplements exhibited similar effects in improving antioxidant levels in the subjects (Nor Azman et al., 2018). Their study showed that TRF had a more significant effect in improving antioxidant levels in females compared to males. The effects of tocotrienols in the prevention of bone loss was systematically reviewed by Radzi et al. (2018) and provided evidence on its inhibitory effects on the bone resorbing cells, i.e. osteoclasts differentiation and activity, further suggesting tocotrienols as a potential antioxidant in the prevention and treatment of bone-related diseases characterised by increased bone loss. Oil palm phenolics (OPP) have been reported to exhibit anti-inflammatory and neuroprotective effects on human astrocyte reactivity in vitro (Weinberg et al., 2018a) and inhibitory effects which prevent the formation of neurotoxic oligomers in vitro (Weinberg et al., 2018b), suggesting a therapeutic potential of OPP for neuroinflammatory conditions in neurodegenerative diseases such as Alzheimer's disease and Parkinsons disease. A recent clinical study evaluating the safety of OPP supplementation in human also showed improved total cholesterol and LDL-C levels in subjects supplemented with OPP compared to the control and suggests OPP as a safe supplement with a protective role in reducing cholesterol levels (Fairus et al., 2018).

\section{‘Green' Oleochemicals}

The Malaysian oleochemical industry today is a world-class player and accounts for $20 \%$ of global capacity, making Malaysia one of the world's largest producers of oleochemicals. As global demands for oleochemicals increased and new technologies emerged, the operations expanded to produce oleochemicals derivatives and consumer or industrial end-products. In this respect, the Malaysian oleochemical industry contributes significant additional revenue over the basic value of commodity oils. The market demand for oleochemicals is projected to grow at a compound annual growth rate (CAGR) of $4.9 \%$ during the period of 2019-2025. South-east Asian countries such as Malaysia, Indonesia, and Thailand are spurring the oleochemical industry in the Asia-Pacific region. Asia-Pacific is depicted as the largest oleochemical producing region to date with a major share of about $41 \%$ in the global oleochemicals market (Industry ARC, 2018). New uses and applications based on green chemicals to replace petrochemicals are driving the growth of oleochemicals market. The major applications of oleochemicals are the manufacturers of soap, surfactants, detergents, rubber and plastics, paper, lubricants, cosmetics and personal care products, textile auxiliaries, paints and pharmaceuticals (Kushairi and Parveez, 2017).

Increase in demand for biodegradable products and sustainable solutions, coupled with changes in regulations in recent years are increasing the influence of oleochemicals in various segments of chemical industry. Recent R\&D efforts have focused upon oleochemicals derivatives such as bio-polyol for polyurethanes (PU), surfactants and bio-surfactants, bio-lubricants, agrochemicals and glycerol derivatives, and assessing the feasibility of processes and technologies, and their environmental impacts. Even though oleochemicals compete sideby-side with petrochemicals in various markets, palm-based oleochemicals are gaining better consumer acceptance due to the growing demand for eco-friendly chemicals.

The preparation of palm-based polyols from renewable raw materials, such as palm kernel olein, fatty acid methyl ester and oleic acid, is highly desirable to reduce the dependency on petroleumbased raw materials (Norhayati et al., 2018). The K10 montmorillonite catalyst can be recycled to produce polyol from epoxidised palm olein with similar quality with polyol prepared from fresh catalyst. This offer cost benefit by reducing the cost of polyol production.

Thermoplastic polyurethanes (TPU) are some of the most diverse polymers and due to their performance have found use in a broad range of applications such as automotive instrument panels, caster wheels, power tools, sporting goods, medical 
devices, and a variety of extruded film, sheet and profile applications. Polyester polyols, the most common are petroleum-based adipate polyols, are the key building blocks of TPU soft segment. Tuan Noor Maznee et al. (2018a) has successfully evaluated the structure-property correlation of the renewable azelaic acid-based polyester polyols, or azelate polyols, in TPU. The results can be used as guide to select appropriate azelate polyols to target specific TPU performance.

Commercial availability of fatty acid methyl ester (FAME) from palm oil targeted for biodiesel offers a good feedstock for the production of structurally well-defined polyols for PU applications. The effect of molecular weight (MW), odd and even carbon numbers, and the linear and branched structure reactants used in the ring-opening reaction of epoxidised fatty acid methyl ester (E-FAME) on the properties of polyols was investigated. These findings would be beneficial for formulators in choosing the most cost-effective polyols for PU formulations (Tuan Noor Maznee et al., 2018b).

Cosmetic is one of the elements that bring attractiveness to human. The cosmetic industry has been expanding rapidly in both developed as well as developing countries. The cosmetics market in Asia seems to be one of the fastest growing markets (Selvarajah et al., 2017). As public interest in sustainability continues to climb, many cosmetic manufacturers are seeking more natural and environmental-friendly emulsifiers and ingredients for their products. The 'green' and 'sustainable' cosmetics are defined as cosmetic products using natural ingredients produced from renewable raw materials (Acme-Hardesty, 2019). Bio-based oleochemicals derived from renewable plant, e.g. palm-based oleochemicals such as glycerine, fatty acids, fatty alcohols and their esters, and bacteria sources are the crux of the green cosmetics movement. Recent advances witnessed the application of nanotechnologies in cosmetics industry, which resulted in the introduction of new nanomaterials for topical applications. While there

TABLE 9. THE VALUES OF IC $_{50}$ OF TROLOX, OPAL AND BHT IN DECREASING ORDER OF ANTIOXIDANT ACTIVITY

\begin{tabular}{cc}
\hline Sample $(\mathbf{n}=\mathbf{3})$ & IC50 $\left(\mathbf{m g ~ m l}^{-1}\right)$ \\
\hline Trolox & $0.127 \pm 0.000$ \\
BHT & $0.134 \pm 0.000$ \\
OPAL M1 & $0.461 \pm 0.004$ \\
OPAL M2 & $0.651 \pm 0.005$ \\
OPAL M4 & $1.036 \pm 0.001$ \\
OPAL M3 & $1.330 \pm 0.010$ \\
\hline
\end{tabular}

Note: OPAL - oil palm leaves, Trolox - a positive control. BHT - butylated hydroxytoluene.

$\mathrm{IC}_{50}$ - concentration of sample required to inhibit $50 \%$ of 2,2-diphenyl-1-picrylhydrazyl (DPPH) free radical. are many advantages of using nanomaterials, such as overcoming the issues of limited penetration and low bioavailability of non-soluble bioactive agents, using submicron particles for enhanced skin penetration has raised the concern of safety including the increase potential to induce skin irritation and allergic reactions on the skin. The studies on irritation potential of palm TRF nanoemulsion using in vitro ocular and dermal irritection assays, reconstructed human epidermis and human corneal epithelium tests were investigated by Zafarizal et al. (2018). It was found that palm TRF nanoemulsion does not induce any irritation to the eye and skin. Hence, it is safe to be applied topically.

Many types of phytochemicals have been found to be present in oil palm leaf and could potentially be used as functional ingredients for skincare product. Oil palm leaf extract (OPLE) is gaining considerable interest as it provides many functions such as anti-microbial effect towards bacteria, good UV protection and possesses the ability to combat several skin diseases due to its antioxidant properties. Although the antioxidant activity of the OPLE is less effective than butylated hydroxytoluene (BHT), a synthetic antioxidant, but they can be added at higher amounts to achieve similar antioxidant activity (Table 9). The low $\mathrm{IC}_{50}$ value indicates higher antioxidant activity. The transparency and brightness of transparent soaps formulated with OPLE were not affected at $0.1 \%$ concentration (Figure 3). Thus, it may be used as natural antioxidant and colourant in transparent soaps (Norashikin et al., 2018). However, as of today, there is no published report on hazard identification and safety assessment of OPLE, particularly on skin and eye. The potential hazard of OPLE on skin and eye irritation was evaluated by Nor Zuliana et al. (2018) as an initial step to the safety assessment of OPLE. Hazard identification results showed that OPLE at $1 \%, 5 \%$, and $10 \%$ (wt/ wt) could be classified as non-irritant to the skin and eye, while in vitro cell viability study on normal human dermal fibroblasts showed that OPLE is non-toxic to the cells. Further safety assessment, such as human patch testing, was recommended to confirm the non-irritant of OPLE.

Glyceryl ether is suitable to be used in cosmetic products at reduced viscosity but still retain its skin hydration property. The effects of glyceryl ether, specifically mono-tert-butoxypropanediol, on oil in water emulsion system were studied by Yusrabbil et al. (2018). Emulsions with glyceryl ether showed lower viscosity values than emulsions with glycerol (Figure 4). Furthermore, the emulsions also exhibited moisturising property compared to the control emulsion.

Lubricants are substances which are employed to lubricate contacting surfaces in relative motion to facilitate the movement between two 


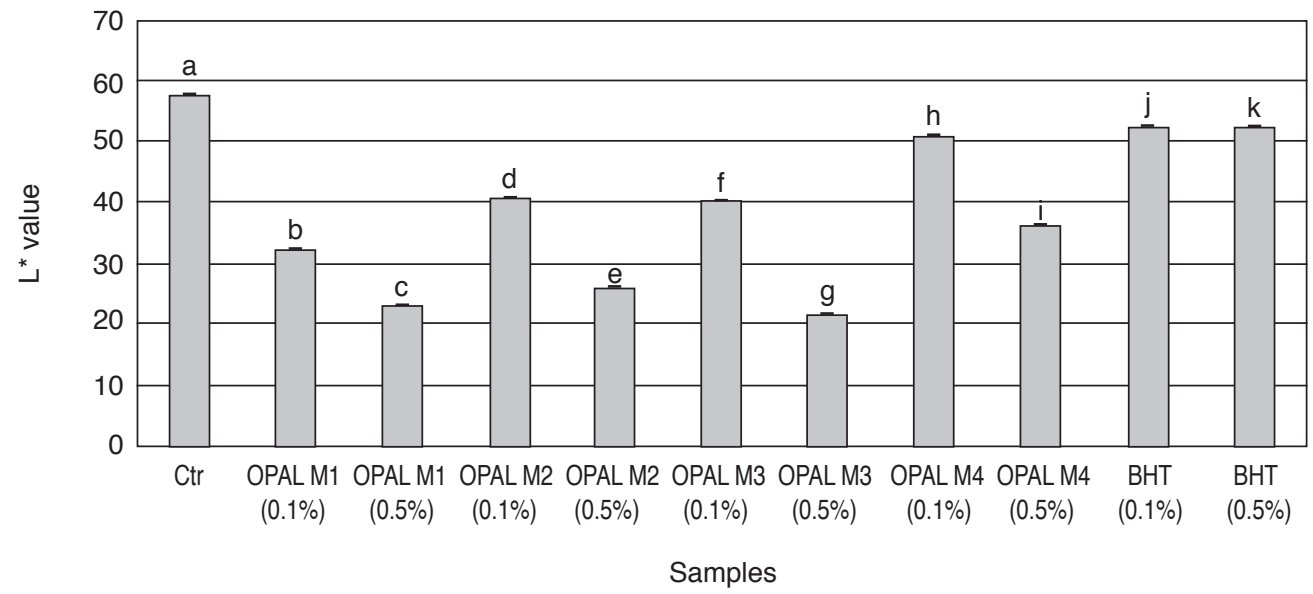

Figure 3. Luminosity of palm-based transparent soap with $0.1 \%$ and $0.5 \%$ oil palm leaf extract (OPEL) extract and butylated hydroxytoluene (BHT). $\mathrm{Ctrl}$ - control sample. Values in the same column followed by different letters indicate significant differences $(p<0.05)$. Lower $L^{*}$ value indicates dark colour of the soap.

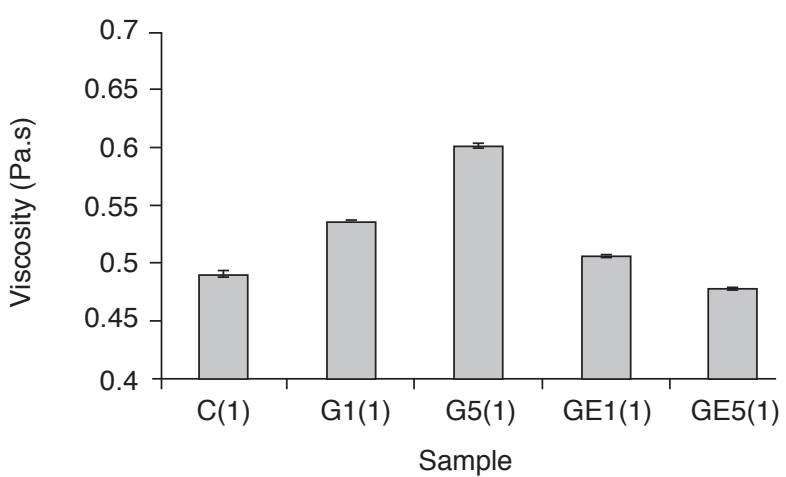

Figure 4. The viscosity of the prepared emulsions. C(1) - placebo, G1(1) - emulsion containing $1 \%$ glycerol, G5(1) - emulsion containing $5 \%$ glycerol, GE1(1) - emulsion containing 1\% glycerol ether and GE5(1) - emulsion containing 5\% glycerol ether.

surfaces by reducing friction and wear. Generally, bio-lubricants are defined as lubricants with a biobased content of at least 25\% and reaching at least 60\% of biodegradability as stated in European Standards (European Committee for Standardisation). It must also be non-toxic to the environment and fulfil the needs of the lubricant application (Chan et al., $2018 b$ ). Hence, vegetable oil, such as palm oil, and oleochemicals such as synthetic esters, have been widely used in bio-lubricant products owing to their renewability, eco-friendly, biodegradability properties and technical performance. Noor Armylisa's et al. (2018) highlighted recent advancement in conversion of waste cooking oil (WCO) and POME into bio-lubricants (Figure 5). Exploration of WCO and POME as raw materials for bio-lubricants not only reduce the cost of starting materials, but could reduce environmental pollution caused by improper disposal of these wastes. These are examples of fully optimised utilisation of palm oil waste into value-added materials (Figure 5).
An easy and efficient method was developed using an esterification process coupled with shortpath distillation to produce high purity palm specialty esters, pentaerythritol ester (PEE). The $\mathrm{C}_{8}-\mathrm{C}_{10}$ fatty-acid esters of pentaerythritol are the bases for high performance lubricants. According to Organisation for Economic Cooperation and Development (OECD) 301F test method, PEE is readily biodegradable and $100 \%$ biodegradability can be achieved in less than nine days. The PEE produced has shown lubricant properties and can be used as a base stock for bio-lubricant composition (Zulina et al., 2018).

In other aspect, a successful formulation of bio-lubricant relies on the selection of suitable biolubricant base stocks and additives to meet a list of specifications required by an application. Chan et al. (2018b) gave a comprehensive review and an in-depth discussion of the tribological behaviours of bio-lubricant base stocks and additives. The influences of bio-lubricant base stocks and additives on tribological performance are summarised in this review. The tribological data presented in this review may assist interested parties in preparing and formulating bio-lubricants which fulfil basic lubrication requirements.

Biosurfactants are defined as surface-active molecules produced by microorganisms. Biosurfactants have diversified applications which include organic chemicals, petroleum, petrochemicals, mining, metallurgy (mainly bioleaching), agrochemicals, fertilisers, foods, beverages, cosmetics and pharmaceuticals due to their unique properties such as specific in their action, biodegradable, low toxicity, biocompatible and relative ease of preparation. They can be used as emulsifiers as well as demulsifiers, wetting agents, foaming agents, spreading agents, functional food ingredients and detergents. The interfacial surface tension 


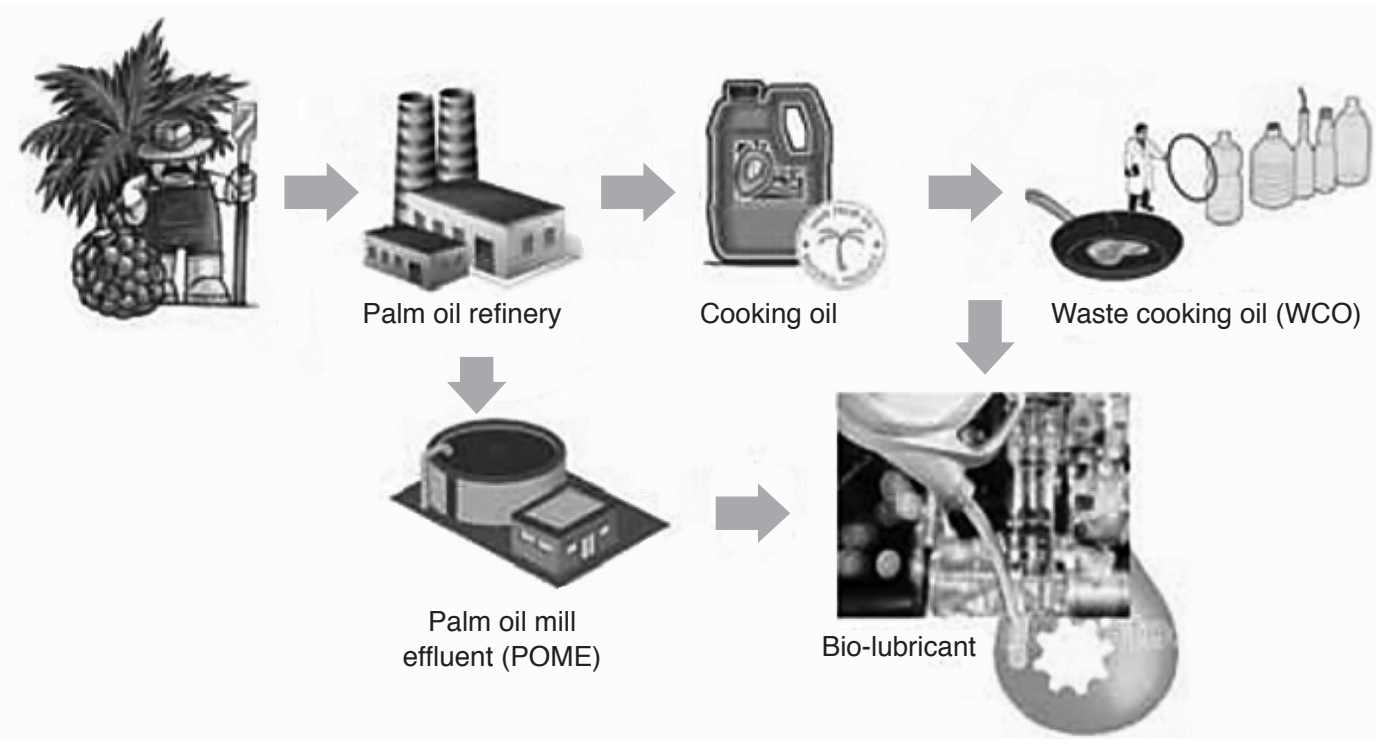

Figure 5. Bio-lubricant production from palm oil waste.

reducing ability of biosurfactants made them very important in oil recovery and bioremediation of heavy crude oil (Vijayakumar and Saravanan, 2015). Sophorolipids (SL), a type of biosurfactant, prepared from biotransformation of refined, bleached and deodourised (RBD) palm olein by Starmerella bombicola (ATCC 22214) occur as a mixture of homologs. Two different purification methods were compared by Wan Nur Fatihah et al. (2018): precipitation and solvent extraction. SL isolated by precipitation contained $70.24 \pm 1.4 \%$ lactone and $29.76 \pm 1.4 \%$ acidic SL, while SL isolated by solvent extraction contained $44.78 \pm 1.9 \%$ lactone and 55.22 $\pm 1.9 \%$ acidic SL. The purification method adopted influenced the composition of the SL products.

\section{CONCLUSION}

With climate change already making an impact as seen from the extreme weathers being experienced now, the industry needs to take steps to mitigate the situation. Technology adoption can be observed throughout the different areas of research and it is clearly driving agricultural and process improvements, and simultaneously ensuring the sustainable development of the industry. It is envisioned that as we gather more scientific data to support the industry and to refute the negative claims, policies that are detrimental to the wellbeing of the palm oil industry such as the EU ban, should be re-examined. Otherwise, it would be seen purely as a discriminatory act against palm oil. In addition, many are saying denying palm oil in toto even though they are sustainably produced, would do more harm than good.

\section{ACKNOWLEDGEMENT}

The authors wish to thank all from the different divisions at MPOB for their contribution to this article.

\section{REFERENCES}

Acme-Hardesty (2019). Green cosmetics: The push for sustainable beauty. https://www. acme-hardesty.com/green-cosmetics-sustainablebeauty /, accessed on 26 February 2019.

Ainatun Nadirah, Z; Hazlina, A Z and Wahizatul, A A (2018). Food consumption, developmental time, and protein profile of the digestive system of the red palm weevil, Rhynchophorus ferrugineus (Coleptera: dryophthoridae) larvae reared on three different diets. J. Insect Science, 18(10): 1-7.

Alessandro, N G; de Oliveira Fabera, M; De Sa, L R V and Ferreira-Leitão, V S (2018). Palm oil mill effluent (POME) as raw material for bio-hydrogen and methane production via dark fermentation. Renewable and Sustainable Energy Reviews, 92: 676684.

Anderson, J M (2008). Eco-friendly approaches to sustainable palm oil production. J. Oil Palm Res. Special Issue (October 2008): 127-142.

Angel, L P L; Sundram, S; Tay, B Y P; Yusof, M T and Ismail, I S (2018). Profiling of anti-fungal activity of Trichoderma virens $159 \mathrm{c}$ involved in biocontrol assay of Ganoderma boninense. J. Oil Palm Res. Vol. 30(1): 8393. 
Archer, S A; Murphy, R J and Wilckens, R S (2018). Methodological analysis of palm oil biodiesel life cycle studies. Renewable and Sustainable Energy Review, 94: 694-704.

Arisseto, A P; Silva, W C; Tivanello, R G; Sampaio, K A and Vicente, E (2018a). Recent advances in toxicity and analytical methods of monochloropropanediols and glycidyl fatty acid esters in foods. Current Opinion in Food Science, 24: 36-42.

Arisseto, AP; Silva, W C; Marcolino, P F C; Scaranelo, G R; Berbari, S A G; de Oliveira Miguel, A M R and Vicente, E (2018b). Influence of potato cultivar, frying oil and sample pre-treatments on the contamination of French fries by 3-monochloropropane-1, 2-diol fatty acid esters. Food Research International. DOI: doi.org/10.1016/j.foodres.2018.10.070

Aroonluk, S; Roytrakul, S; Yingchutrakul, Y; Kittisenachai, S and Jantasuriyarat, C (2018). Identification and characterization of glycoproteins during oil palm somatic embryogenesis. Agriculture and Natural Resources, 52: 430-438.

Awang, A H; Khairuman, H; Ramli, Z; Ibrahim, I and Azian, F U M (2018). The effects of technology transfer and adoption on independent oil palm smallholders' productivity. J. International Information Institute, 21(6): 1695-1704.

Azman, I and Nazirah, C J (2018). The effects of establishing Sustainable Oil Palm Growers' Cooperatives on the incomes of oil palm smallholders. Oil Palm Industry Economic J. Vol. 15(1): 1-7.

Azman, I; Siti Mashani, A; Ali, Z A N; Nur Nadia, K; Ainul, S S; Khairuman, H; Mohamad Arfan, J; Shakir, A and Balu, N (2018a). Labour requirement in the oil palm independent smallholder sector in Sabah and Sarawak, Malaysia. Oil Palm Industry Economic J. Vol. 18(2): 37-45.

Azman, I; Zulhusni, A; Norhidayu, A; Mashani, S; Khairuman, H; Ainul, S and Balu, N (2018b). Labour requirements in the independent oil palm smallholder sector in Peninsular Malaysia. Oil Palm Industry Economic J. Vol. 18(1): 41-49.

Azmi, W A; Chong, J L; Zakeri, H A; Yusuf, N; Omar; W B W; Yong, K W; Zulkefli, A N and Hussain, M H (2017). The red palm weevil, Rhynchophorus ferrugineus: Current issues and challenges in Malaysia. Oil Palm Bulletin No. 74: 17-24.

Bahari, M N A; Sakeh, N M; Abdullah, S N A; Ramli, R R and Kadkhodaei, S (2018). Transciptome profiling at early infection of Elaeis guineensis by
Ganoderma boninense provides novel insights on fungal transition from biotrophic to necrotrophic phase. BMC Plant Biology, 18: 1-25.

Bai, B; Wang, L; Lee, M; Zhang, Y J; Rahmadsyah; Alfiko, Y; Ye, B Q; Wan, Z Y; Lim, C H; Suwanto, A; Chua, N H and Yue, G H (2017). Genome-wide identification of markers for selecting higher oil content in oil palm. BMC Plant Biology, 17: 93. DOI: 10.1186/s12870-017-1045-z.

Bai, B; Wang, L; Zhang, Y J; Lee, M; Rahmadsyah, R; Alfiko, Y; Ye, B Q; Purwantomo, S; Suwanto, A; Chua, N H and Yue, G H (2018a). Developing genome-wide SNPs and constructing an ultrahighdensity linkage map in oil palm. Scientific Reports, 8: 691. DOI: 10.1038/s41598-017-18613-2.

Bai, B; Zhang, Y J; Wang, L; Lee, M; Rahmadsyah, R; Ye, B Q; Alfiko, Y; Purwantomo, S; Suwanto, A and Yue, G H (2018b). Mapping QTL for leaf area in oil palm using genotyping by sequencing. Tree Genetics $\mathcal{E}$ Genomes, 14: 31. https:/ / doi.org/10.1007/s11295018-1245-1

Basiron, Y and Yew, F K (2015). Land use impacts of the livestock and palm oil industries. J. Oil Palm, Environment and Health, 6: 1-9.

Berkelmann, D; Schneider, D; Engelhaupt, M; Heinemann, M;Christel,S; Wijayanti, M;Meryandini, $M$ and Daniel, R (2018). How rainforest conversion to agricultural systems in Sumatra (Indonesia) affects active soil bacterial communities. Frontiers in Microbiology, 9: 1-13.

Bhattacharyya, P N; Goswami, M P and Bhattacharyya, L H (2016). Perspective of beneficial microbes in agriculture under changing climatic scenario: A review. J. Phytology, 8: 26-41.

Brinkman, M L J; Hilst, F V D; Faaij, A P C and Wicke, B (2018). Low-ILUC-risk rapeseed biodiesel: Potential and indirect GHG emission effects in Eastern Romania. J. Biofuels. DOI: doi.org/10.1080/ 17597269.2018.1464873.

Brouder, S M and Volenec, J J (2008). Impact of climate change on crop nutrient and water use efficiencies. Physiologia Plantarum, 133(4): 705-724.

Chan, Y H; Yusup, A; Quitain, A T; Chai, Y H; Uemura, Y and Loh, S K (2018a). Extraction of palm kernel shell derived pyrolysis oil by supercritical carbon dioxide: Evaluation and modelling of phenol solubility. Biomass and Bioenergy, 116: 106-112.

Chan, C H; Tang, S W; Mohd N K; Lim, W H; Yeong, S K and Idris, Z (2018b). Tribological behaviour of 
biolubricant base stocks and additives. Renewable and Sustainable Energy Reviews, 93: 145-157.

Chang, S H (2018). Bio-oil derived from palm empty fruit bunches: Fast pyrolysis, liquefaction and future prospects. Biomass and Bioenergy, 119: 263-276.

Che Idris, C A; Sundram, K and Abdul Razis, A F (2018). Effect of consumption heated oils with or without dietary cholesterol on the development of atherosclerosis. Nutrients, 10(10): 1527.

Cheng, C; Wang, D; Xia, H; Wang, F; Yang, X; Pan, D; Wang, S; Yang, L; Lu, H; Shu, G and He, Y (2018). A comparative study of the effects of palm olein, cocoa butter and extra virgin olive oil on lipid profile, including low-density lipoprotein subfractions in young healthy Chinese people. International J. Food Sciences and Nutrition. DOI: 10.1080/09637486.2018.1504009.

Chin, K L; H'ng, P S; Maminski, M; Go, W Z; Lee, C L; Raja-Nazrin, R A; Khoo, P S; Ashikin, S N and Halimatun, I (2018). Additional additives to reduce ash related operation problems of solid biofuel from oil palm biomass upon combustion. Industrial Crops and Products, 123: 285-295

Choong, Y Y; Chou, K W and Norli, I (2018). Strategies for improving biogas production of palm oil mill effluent (POME) anaerobic digestion: A critical review. Renewable and Sustainable Energy Reviews, 82: 2993-3006.

Corley, R H V; Rao, V; Palat, T and Praiwan, T (2018). Breeding for drought tolerance in oil palm. J. Oil Palm Res. Vol. 30(1): 26-35.

Custodio-Mendoza, J A; Lorenzo, R A; Valente, I M; Almeida, P J; Lage, M A; Rodrigues, J A and Carro, A M (2018). Development of a partitioned liquidliquid extraction-dispersive solid phase extraction procedure followed by liquid chromatographytandem mass spectrometry for analysis of 3-monochloropropane-1, 2-diol diesters in edible oils. J. Chromatography A, 1548: 19-26.

D' Enghien, P B (2016). Davos and Food security: The facts on oilseed efficiency. https://theoilpalm. $\mathrm{org} /$ davos-and-food-security-the-facts-on-oilseedefficiency/, accessed on 25 May 2019.

Dalvi, N; Salvi, B; Chavan, S and Kandalkar, M P (2010). High density planting in mango. J. Horticultural Science, 5(2): 117-119.

Dembilio, Ó; Moya, P; Vacas, S; Ortega-García, L; Quesada-Moraga, E; Jaques, J A and Navarro-Llopis, V (2018). Development of an attract-and-infect system to control Rhynchophorus ferrugineus with the entomopathogenic fungus Beauveria bassiana. Pest Management Science, 74(8): 1861-1869.

Di Genova, L; Cerquiglini, L; Penta, L; Biscarini, A and Esposito, S (2018). Pediatric age palm oil consumption. International J. Environmental Research and Public Health, 15: 651. DOI:10.3390/ ijerph15040651.

Dislich, C; Keyel, A C; Salecker, J; Kisel, Y; Meyer, K M; Auliya, M; Barnes, A D; Corre, M D; Darras, K; Faust, H; Hess, B; Klasen, S; Knohl, A; Kreft, H; Meijide, A; Nurdiansyah, F; Otten, F; Pe'er, G; Steinebach, S; Tarigan, S; Tolle, M H; Tscharntke, T and Wiegand, K (2017). A review of the ecosystem functions in oil palm plantations, using forests as a reference system. Biological Reviews of the Cambridge Philosophical Society, (49): 1539-1569.

DOA (Department of Agriculture) (2016). Report on Current Status of Attack of the Red Palm Weevil, Rhynchophorus ferrugineus in Terengganu. Biosecurity Division, Department of Agriculture, Government Press, Malaysia.

Dommain, R; Frolking, S; Jeltsch-Thömmes, A; Joos, F; Couwenberg, J and Glaser, P H (2018). A radiative forcing analysis of tropical peatlands before and after their conversion to agricultural plantations. Global Change Biology, 24(11): 5518-5533.

European Commission (2018). Amending Regulation (EC) 1881/2006 as regards maximum levels of glycidyl fatty acid esters in vegetable oils and fats, infant formula, follow-on formula and foods for special medical purposes intended for infants and young children. Official J., L55: 27-29.

Fairus, S; Leow, S S; Mohamed, I N; Tan, Y A; Sundram, K and Sambanthamurthi, R (2018). A phase I single-blind clinical trial to evaluate the safety of oil palm phenolics (OPP) supplementation in healthy volunteers. Scientific Reports, 8(1): 8217. https://doi.org/10.1038/s41598-018-26384-7

Fitzherbert, E B; Matthew, J; Struebig, M J; Morel, A; Danielsen, F; Bruhl, C A; Paul F Donald, P F and Phalan, B (2008). How will oil palm expansion affect biodiversity? Trends in Ecology and Evolution, 23(10): 538-545.

Gan, L T; Ho, C Y; Lam, K S and Chew, J S (1995). Optimum harvesting standards to maximize labour productivity and oil recovery. Proc. of the 1993 PORIM International Oil Palm Congress - Update and Vision. p. 195-211.

Ganesan, K; Sukalingam, K and Xu, B (2018). Impact of consumption and cooking manners of 
vegetable oils on cardiovascular diseases - A critical review. Trends in Food Science \& Technology, 71: 132-154.

Gao, H; Kadirjan-Kalbach, D; Froehlich, J E and Osteryoung, KW (2003). ARC5, a cytosolic dynaminlike protein from plants, is part of the chloroplast division machinery. Proc. of the National Academy of Science USA, 100: 4328-4333.

Goggin, K A and Murphy, D J (2018). Monitoring the traceability, safety and authenticity of imported palm oils in Europe. Oilseeds \& Fats Crops and Lipids, 25(6): A603. https: / / doi.org/10.1051/ ocl/2018059

Goh, K M; Wong, Y H; Ang, M Y; Yeo, S C M; Abas, F; Lai, O M and Tan, C P (2018). Comparison assessment between SIM and MRM mode in the analysis of 3-MCPD ester, 2-MCPD ester and glycidyl ester. Food Research International. DOI: doi. org/10.1016/j.foodres.2018.12.013.

Habu, M; Khairulmazmi, A and Nusaibah, S A (2018). Assessment on Trichoderma spp. mixture as a potential biocontrol agent of Ganoderma boninense infected oil palm seedlings. J. Oil Palm Res.Vol. 30 (3): 403-415.

Henson, I E (1989). Modelling gas exchange, yield and conversion efficiency. Workshop on Productivity of Oil Palm. PORIM, Bangi.

Henson, I E (2000). Modelling the effects of 'haze' on oil palm productivity and yield. J. Oil Palm Res. Vol. 12: 123-134.

Henson, I E (2009). Modelling Dry Matter Production, Partitioning and Yield of Oil Palm. OPRODSM: A Mechanistic Simulation Model for Teaching and Research. Technical Manual and Users' Guide. MPOB, Bangi. 95 pp.

Higgins, V and Richards, C (2018). Framing sustainability: Alternative standards schemes for sustainable palm. J. Rural Studies. DOI: doi. org/10.1016/j.jrurstud.2018.11.001.

Husri, M N and Ong-Abdullah, M(2018). Importance of KUP8 for $\mathrm{K}+$ uptake in rooted plantlets of Elaeis guineensis under $\mathrm{K}+$ sufficient conditions. South African J. Botany, 118: 65-75.

Idris, N A; Loh, S K; Lau, L N H; Tan, C Y; Mustafa, E M; Vello, V and Phang, S M (2018). Palm oil mill effluent as algae cultivation medium for biodiesel production. J. Oil Palm Res. Vol. 30(1): 141-149.

Industry ARC (2018). Oleochemicals market: By type, by form, by raw material, by refining methods, by post production processes, by derivatives, by application areas, by end user industry, by geography - Forecast (2019-2025). https://industryarc. com/Report/11661/oleochemicals-market-analysis.html, accessed on 1 March 2019.

Isaac, I L; Walter, A W C Y; Bakar, M F A; Idris, A S; Bakar, F D A; Bharudin, I and Murad, A M A (2018). Transcriptome datasets of oil palm pathogen Ganoderma boninense. Data in Brief, 17: 1108-1111.

Ismail, S R; Maarof, S K; Ali, S S and Ali, A (2018). Systematic review of palm oil consumption and the risk of cardiovascular disease. PLoS ONE, 13(2): p.e0193533.

Izzuddin, M A; Nisfariza, M N; Ezzati, B; Idris, A S; Steven, M D and Boyd, D (2018). Analysis of airborne hyperspectral image using vegetation indices, red edge position and continuum removal for detection of Ganoderma disease in oil palm. J. Oil Palm Res. Vol. 30(3): 416-428.

Jelani, A R; Hitam, A; Jamak, J; Mohamed, A; Gono, Y; Ismail, F and Nor, M M (2008). Motorized chisel (Ckat) for short palm harvesting. MPOB Information Series No. 409: 4 pp.

Jelani, A R; Mohd Rizal, M; Mohd Ikmal, A; Yosri, G; Zahara, M; Syahmin, S; Asyraf, A; Asyraf, A; Azwan, B; Aminulrashid, M; Mohamad Borhan, S; Azman, I; Mohd Solah, D; Abd Rahim, S; Norman, K and Kushairi, A (2018). Development and evaluation of a new generation oil palm motorized cutter (Cantas Evo). J. Oil Palm Res. Vol. 30(2): 276-288.

Kahn, P C; Molnar, T; Zhang, G G and Funk, C R (2011). Investing in perennial crops to sustainably feed the world. Issues in Science and Technology, 27(4): 75 .

Khaled, A Y; Aziz, S A; Bejo, S K, Nawi, N M; Idris, A $S$ and Izzuddin, M A (2018). Development of classification models for basal stem rot (BSR) disease in oil palm using dielectric spectroscopy. Industrial Crops and Products, 124: 99-107.

Khasanah, N and Van Noordwijk, M (2019). Subsidence and carbon dioxide emissions in a smallholder peatland mosaic in Sumatra, Indonesia. Mitigation and Adaptation Strategies for Global Change, 24(1): 147-163.

Knutsen, H K; Alexander, J; Barregård, L; Bignami, M; Brüschweiler, B; Ceccatelli, S; Cottrill, B; Dinovi, M; Edler, L; Gras-Kraupp, B and Hoogenboom, L R (2018). Update of the risk assessment on 3-monochloropropane diol and its fatty acid esters. EFSA J., 16(1): e05083. DOI: 10.2903/j. efsa.2018.5083. 
Kumari, D and Singh, R (2018). Pre-treatment of lignocellulosic wastes for biofuel production: A critical review. Renewable and Sustainable Energy Reviews, 90: 877-891.

Kushairi, A and Balu, N (2018). Malaysian palm oil - Performance and prospects. Global Oils $\mathcal{E}$ Fats Business Magazine, 15(3): 27-30.

Kushairi, A and Parveez, G K A (2017). Chapter 8. Decade: 1980-1989. The Oil Palm Saga. MPOB, Bangi. p. 84-117.

Kushairi, A; Loh, S K; Azman, I; Hishamuddin, E; Ong-Abdullah, M; Izuddin, Z B; Razmah, G; Sundram, S and Parveez, G K A (2018). Oil palm economic performance in Malaysia and R\&D progress in 2017. J. Oil Palm Res. Vol. 30: 163-195.

Kyselka, J; Matějková, K; Šmidrkal, J; Berčíková, M; Pešek, E; Bělková, B; Ilko, V; Doležal, M and Filip, V (2018). Elimination of 3-MCPD fatty acid esters and glycidyl esters during palm oil hydrogenation and wet fractionation. European Food Research and Technology, 244(11): 1887-1895.

Lau, Y C B; Othman, A and Ramli, U S (2018a). Application of proteomics technologies in oil palm research. The Protein J. DOI: doi.org/10.1007/s10930018-9802-x.

Lau, H S; Ng, H K; Gan, S and Jourabchi, S A (2018b). Torrecfaction of oil palm fronds for co-firing in coal power plants. Energy Procedia, 144: 75-81.

Leblanc, H A and Russo, R O (2008). Carbon sequestration in an oil palm crop system (Elaeis guineensis) in the Caribbean Lowlands of Costa Rica. Proc. of the Florida State Horticultural Society, 121: 5254.

Lee, K W; Omar, D; Cheng, G L E, Nasehi, A and Wong, M Y (2018a). Characterization of phenazine and phenazine-1-carboxylic acid isolated from Pseudomonas aeruginosa UPMP3 and their antifungal activities against Ganoderma boninense. Pertanika J. Tropical Agricultural Science, 41: 1795-1809.

Lee, F C; Ong-Abdullah, M; Ooi, S E; Ho, C L and Namasivayam, P (2018b). Cloning and characterization of somatic embryogenesis receptor kinase I (EgSERK I) and its association with callus initiation in oil palm. In vitro Cellular \& Developmental Biology - Plant, 55:153-164.

Lee, S T; Voon, P T; Ng, T K W; Esa, N; Lee, V K M; Abu Saad, H and Loh, S P (2018c). Effects of palmbased high-oleic blended cooking oil diet on selected biomarkers of inflammation and obesity compared to extra virgin olive oil diet in overweight Malaysian adults. J. Oil Palm Res. Vol. 30(2): 289-298.

Lim, F H; Rasid, O A; Idris, A S and Parveez, G K A (2018a). Molecular cloning of Ganoderma boninense HOG1-type mitogen-activated protein kinase (MAPK) cDNA and transcriptional response to salinity stress. J. Oil Palm Res. Vol. 30(3): 380-389.

Lim, S L; Subramaniam, S; Zamzuri, I and Amir, H G (2018b). Growth and biochemical profiling of artificially associated micropropagated oil palm plantlets with Herbaspirillum seropedicae. J. Plant Interactions, 13(1): 173-181.

Loganathan, R; Vethakkan, S R; Radhakrishnan, A K; Razak, G A and Kim-Tiu, T (2018). Red palm olein supplementation on cytokines, endothelial function and lipid profile in centrally overweight individuals: A randomised controlled trial. European J. Clinical Nutrition. DOI: 10.1038/s41430-018-0236-5.

Loh, S K; Kassim, M A and Bukhari, N A (2018). Optimisation of process conditions for ethanol production from enzymatically saccharified empty fruit bunch using response surface methodology (RSM). J. Oil Palm Res. Vol. 30(4): 642-654.

Madihah, A Z; Maizatul-Suriza, M; Idris, A S; Bakar, M F A; Kamaruddin, S 1; Bharudin, I; Abu Bakar, F D and Murad, A M A. (2018). Comparison of DNA extraction and detection of Ganoderma, causal of basal stem rot disease in oil palm using loop-mediated isothermal amplification. Malaysian Applied Biology, 47(5): 119-127.

Madon, M; Yahaya I, and Parveez G K A (2018). Transgenic oil palm analysis via fluorescence in situ hybridisation, flow cytometry and cytological techniques. J. Oil Palm Res. Vol. 30 (4): 548-558.

Majid, I; Khalil, A and Nazir, N (2018). Economic analysis of high density orchards. International J. Advance Research in Science and Engineering, 7(4): 821829.

Manley, M; Melzer, M and Spafford, H (2018). Oviposition preferences and behavior of wildcaught and laboratory-reared coconut rhinoceros beetle, Oryctes rhinoceros (Coleoptera: scarabaeidae), in relation to substrate particle size. Insects, 9(4):141. DOI: 10.3390 / insects9040141.

Masani, A M Y; Dayang Izawati, A M; Omar, A R and Parveez, G K A (2018). Biotechnology of oil palm: Current status of oil palm genetic transformation. Biocatalysis and Agricultural Biotechnology, 15: 335347. 
Melling, L; Goh, K J; Kloni, A and Hatano, R (2012). Is the water table the most important factor influencing soil C-flux in tropical peatland? Proc. of the $14^{\text {th }}$ International Peat Congress. International Peat Society, Stockholm, Sweden. Extended Abstract No. 330. 6 pp.

Melling, L; Hatano, R and Goh, K J (2005). Soil CO flux from three ecosystems in tropical peatland of Sarawak, Malaysia. Tellus, 57: 1-11.

Merkle, S; Ostermeyer, U; Rohn, S; Karl, H and Fritsche, J (2018a). Mitigation strategies for ester bound 2-/3-MCPD and esterified glycidol in pre-fried breaded and frozen fish products. Food Chemistry, 245: 196-204.

Merkle, S; Ostermeyer, U; Rohn, S; Karl, H and Fritsche, J (2018b). Formation of ester bound 2-and 3-MCPD and esterified glycidol in deep-fried and pickled herring products. European J. Lipid Science and Technology, 120(7): 1700464. https: / doi. org/10.1002/ ejlt.201700464

Miller, R (2015). Smart land use: Palm oil is the world's most efficient oil crop. https://www. palmoilhealth.org / sustainability / most-efficientoil-crop/, accessed on 25 May 2019.

Mo, S Y; Lai, O M; Chew, B H; Ismail, R; Bakar, S A; Jabbar, N A and Teng, K T (2018). Interesterified palm olein lowers postprandial glucose-dependent insulinotropic polypeptide response in type 2 diabetes. European J. Nutrition: 1-13. DOI: 10.1007/ s00394-018-1738-6.

Mohd Shawal, M T; Sakinah, S; Nur Aziemah, A G; Syarifah Azura, S I; Shamsilawani, A B; Mohamed Mazmira, M M and Siti Ramlah, A A (2018). Prokaryotic biodiversity in matured oil palm plantation compared to logged-over and primary forest in deep peat, Sarawak, Malaysia. J. Oil Palm Res. Vol. 30(3): 451-463.

Montúfar, R; Louise, C and Tranbarger, T J (2018). Elaeis oleifera (Kunth) Cortés: A neglected palm from the Ecuadorian Amazon. Revista Ecuatoriana De Medicina Y Ciencias Biologicas, 39 (1): 11-18.

MPOB (2019). Malaysian Oil Palm Statistics 2018. $38^{\text {th }}$ Edition. MPOB, Bangi. 280 pp.

Muhamad, N A; Mustapha, N; Baharin, M F; Mutalip, M H A; Malek, M A; Salleh, R; Zaki, N A M; Othman, F; Aris, T T and Murad, S (2018). Impact of palm oil versus other oils on weight changes: A systematic review. Food and Nutrition Sciences, 9: 915-936.
Murphy, D J (2018). Advances in the genetic modification of oil palm. Achieving Sustainable Cultivation of Oil Palm Volume 1: Introduction, Breeding and Cultivation Techniques (Rival, A ed.). Burleigh Dodds Science Publishing, Cambridge, United Kingdom. http://dx.doi.org/10.19103/ AS.2017.0018.09

Nagappan, J; Chin, C F; Angel, L P L; Cooper, R M; May, S T and Low, E T L (2018). Improved nucleic acid extraction protocols for Ganoderma boninense, G. miniatocinctum and G. tornatum. Biotechnology Letters, 40(11-12): 1541-1550.

Naidu, Y; Siddiqui, Y; Rafii, M Y and Saud, H M (2018). Inoculation of oil palm seedlings in Malaysia with white-rot hymenomycetes: Assessment of pathogenicity and vegetative growth. Crop Protection, 110: 146-154.

Nambiappan, B; Ismail, A; Hashim, N; Ismail, N; Shahari, D N; Nik Idris, N A; Omar, N; Kamalrudin Mohamed Salleh, K; Mohd Hassan, N A and Kushairi, A (2018). Malaysia: 100 years of resilient palm oil economic performance. J. Oil Palm Res. Vol. 30(1): 13-25.

Navarro-Llopis, V; Primo, J and Vacas, S (2018). Improvements in Rhynchophorus ferrugineus (Coleoptera: Dryophthoridae) trapping systems. J. Economic Entomology, 111(3): 1-8.

$\mathrm{Ng}$, K H; Cheng, Y W; Lee, Z S and Cheng, C K(2018). A study into syngas production from catalytic steam reforming of palm oil mill effluent (POME): A new treatment approach. International J. Hydrogen Energy. DOI: doi.org/10.1016/j.ijhydene.2018.04.232.

Noor Armylisa's, A H; Siti Hazirah, M F and Yeong, S K (2018). Potential of palm oil waste for biolubricant. Palm Oil Developments No. 68: 18-21.

Nor Azman, N; Goon, J; Abdul Ghani, S; Hamid, Z and Wan Ngah, W (2018). Comparing palm oil, tocotrienol-rich fraction and $\alpha$-tocopherol supplementation on the antioxidant levels of older adults. Antioxidants, 7(6): 74. DOI: 10.3390/ antiox7060074.

Nor Zuliana, Y; Zafarizal, A A H and Idris, Z (2018). Skin and eye irritation assessment of oil palm (Elaeis guineensis) leaf extract for topical application. International J. Toxicology, 37(4): 335-343.

Norashikin, A; Azizul Hasan, Z A; Muhamad, H; Bilal, S H; Yusof, N Z and Idris, Z (2018). Determination of total phenol, flavonoid, antioxidant activity of oil palm leaves extracts and their application in transparent soap. J. Oil Palm Res. Vol. 30(3): 315-325. 
Norhayati, M N; Hoong, S S; Tuan Ismail, T N M; Hanzah, N A; Yeong, S K and Idris, Z (2018). Performance of recycled K10 montmorillonite catalyst in the alcoholysis of epoxidised palm olein. J. Oil Palm Res. Vol. 30(3): 326-337.

Nurulhidayah, S A and Norman, K (2016). Growth and longevity of the insect predator, Syacanus dichotomus Stal. (Hemiptera: Reduviidae) fed on live insect larvae. J. Oil Palm Res. Vol. 28(3): 471-478.

Oettli, P; Behera, S K and Yamagata, T (2018). Climate based predictability of oil palm tree yield in Malaysia. Scientific Reports, 8: 2271. DOI:10.1038/ s41598-018-20298-0.

Ong-Abdullah, M; Ordway, J M; Jiang, N; Ooi, S E; Kok, S Y; Sarpan, N; Azimi, N; Hashim, A T; Ishak, Z; Rosli, S K; Malike, F A; Abu Bakar, N A; Marjuni, M; Abdullah, N; Yaakub, Z; Mohd Din, A; Nookiah, R; Singh, R; Low, E T L; Chan, K L; Azizi, N; Smith, S W; Bacher, B; Budiman, M A; Van Brunt, A; Wischmeyer, C; Beil, M; Hogan, M; Lakey, N; Lim, C C; Arulandoo, X; Wong, C K; Choo, C N; Wong, W C; Kwan, Y Y; Syed Alwee, S S R; Sambanthamurthi, R and Martienssen, R A (2015). Loss of karma transposon methylation underlies the mantled somaclonal variant of oil palm. Nature, 525: 533-537.

Onwude, D I; Chen, G; Hashim, N; Esdaile, J R; Gomes, C; Khaled, A Y; Alonge, A F and Ikrang, E (2018). Mechanization of agricultural production in developing countries. Advances in Agricultural Machinery and Technologies (Chen, G ed.) CRC Press Taylor \& Francis Group, London, United Kingdom. p. 3-22.

Ooi, S E; Sarpan, N; Abdul Aziz, N; Nuraziyan, A and Ong-Abdullah, M (2018). Differential expression of heat shock and floral regulatory genes in pseudocarpel initials of mantled female inflorescences from Elaeis guineensis Jacq. Plant Reproduction. DOI:10.1007/s00497-018-0350-5.

Pacheco, P; Gnych, S; Dermawan, A; Komarudin, $\mathrm{H}$ and Okarda, B (2017). The palm oil global value chain implications for economic growth and social and environmental sustainability. Center for International Forestry Research (CIFOR). Working Paper 220.

Parveez, G K A and Majid, N A (2018). Green fluorescent protein as a visual selection marker for oil palm transformation. Industrial Crops and Products, 115: 134-145.

Parveez, G K A; Bahariah, B; Ayub, N H; Masani M Y A; Rasid, O A; Tarmizi, A H and Ishak, Z (2015).
Production of polyhydroxybutyrate in oil palm (Elaeis guineensis Jacq.) mediated by microprojectile bombardment of PHB biosynthesis genes into embryogenic calli. Front. Plant Sci., 6: 598. DOI: 10.3389/fpls.2015.00598.

Parveez, G K A; Rasid, O; Zainal, A; Masri, M M; Majid, N A; Fadillah, $\mathrm{H}$ H; Yunus, A M M and Cheah, S C (2000). Transgenic oil palm: Production and projection. Biochemistry Society Transactions, 28(6): 969-972.

Paterson, R R M and Lima, N (2018). Climate change affecting oil palm agronomy, and oil palm cultivation increasing climate change, require amelioration. Ecology and Evolution, 8: 452-461.

Paterson, R R M; Kumar, L; Shabani, F and Lima, N (2017). World climate suitability projections to 2050 and 2100 for growing oil palm. The J. Agricultural Science, 155: 659-702.

Paterson, R R M; Kumar, L; Taylor, S and Lima, N (2015). Future climate effects on suitability for growth of oil palms in Malaysia and Indonesia. Scientific Reports, 5: 14457. https: / / doi.org/10.1038/ srep14457

Pilotti, C A; Gorea, A E and Bonneau, L (2018). Basidiospores as sources of inoculum in the spread of Ganoderma boninense Pat. in oil palm plantations in Papua New Guinea. Plant Pathology, 67(9): 18411849.

Pootakham, W; Jomchai, N; Ruang-areerate, P; Shearman, J R; Sonthirod, C; Sangsrakru, D; Tragoonrung, S and Tangphatsornruang, S (2015). Genome-wide SNP discovery and identification of QTL associated with agronomic traits in oil palm using genotyping-by-sequencing (GBS). Genomics, 105: 288-295.

Pramudito, T E; Agustina, D; Nguyen, T K N and Suwanto, A (2018). A novel variant of narrowspectrum antifungal bacterial lipopeptides that strongly inhibit Ganoderma boninense. Probiotics and Antimicrobial Proteins, 10: 110-117.

President of Indonesia (2011). Instruction of the President of the Republic of Indonesia number 10 of 2011 about suspension of granting of new licenses and improvement of governance of natural primary forest and peatland.

Qureshi, M; Ng, K L A; Khan, S; Abnisa, F and Wan Daud, W M A (2018). A technical review on semicontinuous and continuous pyrolysis process of biomass to bio-oil. J. Analytical and Applied Pyrolysis. DOI: doi.org/10.1016/j.jaap.2018.02.010. 
Radzi, N F M; Ismail, N A and Alias, E (2018). Tocotrienols regulate bone loss through suppression on osteoclast differentiation and activity: A systematic review. Current Drug Targets, 19(9): 10951107.

Rafea, A M A J; Desa, A; Nazmi, M N and Muhammad, S M K (2018). Mechanized harvesting of oil palm fresh fruit bunches: A review. Proc. of the $7^{\text {th }}$ Kuala Lumpur International Agriculture, Forestry and Plantation Conference (KLIAFP7). 1011 December 2018, Hotel Bangi-Putrajaya, Bangi, Malaysia. p. 77-89.

Raghu, A(2018). New dwarf trees set to revolutionize palm oil market. Business Bloomberg, 4 October 2018.

Rashid, T; Gnanasundaram, N; Appusamy, A; Chong, F K and Ferreira-Leitãoa, V S (2018). Palm oil mill effluent (POME) as raw material for biohydrogen and methane production via dark fermentation. Renewable and Sustainable Energy Reviews, 92: 676-684.

Republic of Indonesia (2016). First Nationally Determined Contribution.

Rietjens, I M; Dussort, P; Günther, H; Hanlon, P; Honda, H; Mally, A; O'Hagan, S; Scholz, G; Seidel, A; Swenberg, J and Teeguarden, J (2018). Exposure assessment of process-related contaminants in food by biomarker monitoring. Archives of Toxicology, 92(1): 15-40.

Rosli, R; Amiruddin, N; Abdul Halim, M A; Chan, P L; Chan, K L; Azizi, N; Morris, P E; Low, E T L; Ong-Abdullah, M; Sambanthamurthi, R; Singh, R and Murphy, D J (2018a). Comparative genomic and transcriptomic analysis of selected fatty acid biosynthesis genes and CNL disease resistance genes in oil palm. PLoS ONE, 13(4): e0194792. https: / / doi. org/10.1371/journal. pone.0194792

Rosli, S K; Ishak, Z; Malike, F A; Abu Bakar, N A; Husri, M N; Abu Bakar, D and Tarmizi, A H (2018b). Clonal Palm Series 2 (CPS2). MPOB Information Series No. 782: 2 pp.

Sadhukhan, J; Martinez-Hernandez, E; Murphy, R J; Ng, K S D; Hassim, M H; Ng, K S; Wan, Y K; Md Jaye, I F; Melissa Y; Leung, P H and Andiappan, V (2018). Role of bioenergy, biorefinery and bio-economy in sustainable development: Strategic pathways for Malaysia. Renewable and Sustainable Energy Reviews, 81: 1966-1987.

Santos, I R; Maximiano, M R; Almeida, R F; da Cunha, R N V; Lopes, R; Scherwinski-Pereira, J E and Mehta, A (2018). Genotype-dependent changes of gene expression during somatic embryogenesis in oil palm hybrids (Elaeis oleifera $\times$ E. guineensis). PLoS ONE, 13(12): e0209445. https://doi.org/10.1371/ journal.pone.0209445

Sarpan, N; Ong-Abdullah, M and Ooi, S E (2018). Optimisation of a chromatin immunoprecipitation (Chip) protocol for histone modification in oil palm. J. Oil Palm Res. Vol. 30(2): 242-250.

Selvarajah, K; Amira, N S; Atilla, U N; Syafawani, $S$ and Hafiz, M (2017). The usage of cosmetic in Malaysia: Understanding the major factors that affect the users. Management, 7(1): 48-51. DOI: 10.5923/j.mm.20170701.07.

Shuib, A R; Khalid, M R; Bakri, M A M; Deraman, M S and Norman, K (2018). Development of oil palm loose fruit collecting machine with elevated discharge mechanism (Mark III). International J. Engineering Research and Technology, 7: 193-202.

Sim, B I; Muhamad, H; Lai, O M; Abas, F; Yeoh, C B; Nehdi, IA; Khor, Y P and Tan, CP (2018). New insights on degumming and bleaching process parameters on the formation of 3-monochloropropane-1, 2-diol esters and glycidyl esters in refined, bleached, deodorized palm oil. J. Oleo Science, 67(4): 397-406.

Singh, R; Low, E T L; Ooi, C L L; Ong-Abdullah, M; Ting, N C; Nagappan, J; Nookiah, R; Mohd Din, A; Rosli, R; Mohamad Arif, A M; Chan, K L; Mohd Amin, H; Azizi, N; Lakey, N; Smith, S W; Budiman, M A; Hogan, M; Bacher, B; Van Brunt, A; Wang, C; Ordway, J M; Sambanthamurthi, R and Martienssen, R A (2013b). The oil palm SHELL gene controls oil yield and encodes a homologue of SEEDSTICK. Nature, 500: 340-344.

Singh, R; Ong-Abdullah, M; Low, E T L; Mohamad Arif, A M; Rosli, R; Nookiah, R; Ooi, C L L; Ooi, S E; Chan, K L; Mohd Amin, H; Azizi, N; Nagappan, J; Bacher, B; Lakey, N; Smith, S W; He, D; Hogan, M; Budiman, M A; Lee, E K; DeSalle, R; Kudrna, D; Goicoechea, J L; Wing, R A; Wilson, R K; Fulton, R S; Ordway, J M; Martienssen, R A and Sambanthamurthi, R (2013a). Oil palm genome sequence reveals divergence of interfertile species in Old and New worlds. Nature, 500: 335-339.

Sloan, S; Edwards, D P and Laurance, W F (2012). Does Indonesia's REDD+ moratorium on new concessions spare imminently threatened forests? Conservation Letters, 5: 222-231.

Soh, A C (2018). Applications and challenges of biotechnology in oil palm breeding. IOP Conference Series: Earth and Environmental Science, 183. International Biotechnology Conference on 
Estate Crops, IOP Publishing. DOI: 10.1088/17551315/183/1/012002.

Subramaniam, V and Hashim, Z (2018). Charting the water footprint of the Malaysian oil palm industry. J. Cleaner Production, 178: 675-687.

Sukiran, M A; Loh, S K and Abu Bakar, N (2018). Conversion of pre-treatment oil palm empty fruit bunches into bio-oils and bio-char via fast pyrolysis. J. Oil Palm Res. Vol. 30(1):121-129.

Sulaiman, S; Yusoff, N S; Tan, J S and Lee, Y P (2018). Deciphering the pan-genome of Ganoderma sp. to depict potential genomic components that contribute to Ganoderma boninense pathogenicity. Malaysian Applied Biology J., 47: 71-80.

Sun, G; Xia, H; Yang, Y; Ma, S; Zhou, H; Shu, G; Wang, S; Yang, X; Tang, H; Wang, F and He, Y (2018). Effects of palm olein and olive oil on serum lipids in a Chinese population: a randomized, double-blind, cross-over trial. Asia Pacific J. Clinical Nutrition, 27(3): 572-580.

Sundram, S (2013a). First report: isolation of endophytic Trichoderma from oil palm (Elaeis guineensis Jacq.) and their in vitro antagonistic assessment on Ganoderma boninense. J. Oil Palm Res. Vol. 25(3): 368-372.

Sundram, S (2013b). The effects of Trichoderma in surface mulches supplemented with conidial drenches in the disease development of Ganoderma basal stem rot in oil palm. J. Oil Palm Res. Vol. 25(3): 314-325.

Sundram, S and Intan, N A M A (2017). South American bud rot: A biosecurity threat to South East Asian oil palm. Crop Protection, 101: 58-67.

Sundram, S; Abdullah, F; Ahmad, Z A M and Yusuf, U K (2008). Efficacy of single and mixed treatments of Trichoderma harzianum as biocontrol agents of Ganoderma basal stem rot in oil palm. J. Oil Palm Res. Vol. 20: 470-483.

Surendan, A; Siddiqui, Y; Manickam, S and Ali, A (2018a). Role of benzoic and salicylic acids in the immunization of oil palm seedlings - challenged by Ganoderma boninense. Industrial Crops and Products, 122: 358-365.

Surendan, A; Siddiqui, Y; Saud, H M; Nusaibah, S A and Manickam, S (2018b). Inhibition and kinetic studies of lignin degrading enzymes of Ganoderma boninense by naturally occurring phenolic compounds. J. Applied Microbiology, 125: 876-887.
Tan, S; Chiew, Y; Ahmad, B and Kadir, K (2018). Tocotrienol-rich vitamin E from palm oil (tocovid) and its effects in diabetes and diabetic nephropathy: A pilot phase II clinical trial. Nutrients, 10(9): 1315. https:/ / doi.org/10.3390/nu10091315.

Tanikkul, P; Booyawanich, S and Pisutpaisal, N (2018). Ozonation aided mesophilic biohydrogen production from palm oil mill effluent. International J. Hydrogen Energy. DOI: doi.org/10.1016/j. ijhydene.2018.09.180.

Teh, C B S and Cheah, S S (2018). Modelling crop growth and yield in palm oil cultivation. Achieving Sustainable Cultivation of Oil Palm (Rival, A ed.). Vol.1. Cambridge, UK: Burleigh Dodds Science Publishing. p. 183-227.

Teh, S S; Mah, S H; Gouk, S W; Voon, P T; Ong, A S $\mathrm{H}$ and Choo, Y M (2018a). Effects of palm olein-olive oil blends on fat deposition in diet-induced obese mice. J. Food and Nutrition Research, 6(1): 39-48.

Teh, S S; Ong, A S H; Choo, Y M and Mah, S H (2018b). Sn-2 hypothesis: A review of the effects of palm oil on blood lipid levels. J. Oleo Science, 67(6): 697-706.

Teuscher, M; Gérard, A; Brose, U; Buchori, D; Clough, Y; Ehbrecht, M; Hölscher, D; Irawan, B; Sundawati, L; Wollni, M and Kreft, H (2016). Experimental biodiversity enrichment in oil-palm-dominated landscapes in Indonesia. Frontiers of Plant Science, 7: 1538. DOI:10.3389/ fpls.2016.01538

Thottathil, G P; Jayasekaran, K and Othman, A S (2016). Sequencing crop genomes: A gateway to Improve tropical agriculture. Tropical Life Sciences Research, 27(1): 93-114.

Ting, N C; Mayes, S; Massawe, F; Sambanthamurthi, R; Jansen, J; Syed Alwee, S S R; Seng, T Y; Ithnin, M and Singh, R (2018). Putative regulatory candidate genes for QTL linked to fruit traits in oil palm (Elaeis guineensis Jacq.) Euphytica, 214: 214. https://doi. org / 10.1007/ s10681-018-2296-y

Tiong, S H; Saparin, N; Teh, H F; Ng, T L M; Md Zain, M Z B; Neoh, B K; Md Noor, A; Tan, C P; Lai, O M and Appleton, D R (2018). Natural organochlorines as precursors of 3-monochloropropanediol esters in vegetable oils. J. Agricultural and Food Chemistry, 66(4): 999-1007.

Tuan Noor Maznee, T I; Ibrahim, N A; Sendijarevic, A; Sendijarevic, I; Schiffman, C M; Hoong, S S; Mohd Noor, M A; Poo Palam, K D; Yeong, S K; Idris, Z; Abd Malek, E; Zainuddin, N and Sendijarevic, V (2018a). Oscillatory structure-property correlation 
in azelate polyols and thermoplastic polyurethanes. J. Applied Polymer Science. DOI: 10.1002 / app.46258.

Tuan Noor Maznee, T I; Ibrahim, N A; Mohd Noor, M A; Hoong, S S; Poo Palam, K D; Yeong, S K; Idris, Z; Schiffman, C M; Sendijarevic, I; Abd Malek, E; Zainuddin, $\mathrm{N}$ and Sendijarevic, V (2018b). Oligomeric composition of polyols from fatty acid methyl ester: The effect of ring-opening reactants of epoxide groups. J. Amer. Oil Chem. Soc., 95(4): 509-523.

Turnbull, N; Durand-Gasselin, $\mathrm{T}$ and Cochard, B (2017). PalmElit/CIRADS breeding program and genetic progress. Oil Palm Genetics and Genomics (Soh, A C; Mayes, S and Roberts, J eds.). CRC Press, Atlanta, USA. p. 165-174.

Utomo, C; Tanjung, Z A; Aditama, R; Buana, R F N; Pratomo, A D M; Tryono, R and Liwang, T (2018). Draft genome sequence of the phytopathogenic fungus Ganoderma boninense, the causal agent of basal stem rot disease on oil palm. Genome Announcements, 6(17): e00122-18. https://doi. org/10.1128/genomeA.00122-18.

Van Kraalingen, D W G (1985). Simulation of Oil Palm Growth and Yield. Ph.D thesis, Wageningen Agricultural University, The Netherlands.

Vijayakumar, S and Saravanan, V (2015). Biosurfactants - Types, sources and applications. Research J. Microbiology, 10: 181-192.

Wan Nur Fatihah, W M Z; Nurul Nadhirah, A R; Abdul Rashid, M Y and Hayes, D G (2018). Acid precipitation versus solvent extraction: Two techniques leading to different lactone/acidic sophorolipid ratios. J. Surfactants Detergent. DOI: 10.1002 / jsde. 12223 .

Wang, Y; Htwe, Y M; Ihase, L O; Amin, M; Shi, P; Li, J; Xiao, Y; Cao, H and Lei, X (2018a). Genotypic response of pollen germination in Dura, Pisifera and Tenera oil palm (Elaeis guineensis Jacq.). Euphytica, 214:194. https: / / doi.org/10.1007/ s10681-018-2277-1

Wang, Y; Htwe, Y M; Ihase, L O; Shi, P; Cao, H and Lei, $X$ (2018b). Pollen germination genes differentially expressed in different pollens from Dura, Pisifera and Tenera oil palm (Elaeis guineensis Jacq.). Scientia Horticulturae, 235: 32-38.

Weinberg, R P; Koledova, V V; Schneider, K; Sambandan, T G; Grayson, A; Zeidman, G; Artamonova, A; Sambanthamurthi, R; Fairus, S; Sinskey, A J and Rha, C (2018a). Palm fruit bioactives modulate human astrocyte activity in vitro altering the cytokine secretome reducing levels of $\mathrm{TNF} \alpha$,
RANTES and IP-10. Scientific Reports, 8(1): 16423. DOI: 10.1038/s41598-018-34763-3.

Weinberg, R P; Koledova, V V; Shin, H; Park, J H; Tan, Y A; Sinskey, A J; Sambanthamurthi, R and Rha, C (2018b). Oil palm phenolics inhibit the in vitro aggregation of $\beta$-amyloid peptide into oligomeric complexes. International J. Alzheimer's Disease: Article ID 7608038. https:/ / doi.org/10.1155/2018/7608038

White, J L and Knight, A T (2018). Palm oil supply chain complexity impedes implementation of corporate no-deforestation commitments. Global Environmental Change, 50: 303-313.

Wijedasa, L S; Sloan, S; Page, S E; Clements, G. R; Lupascu, M and Evans, T A (2018). Carbon emissions from South-East Asian peatlands will increase despite emission-reduction schemes. Global Change Biology, 24(10): 4598-4613.

World Growth (2011). The Economic Benefit of Palm Oil to Indonesia. $26 \mathrm{pp}$.

Yusrabbil, AY;Ariffin, A and AzizulHasan, ZA(2018). Glyceryl ether (mono-tert-butoxypropanediol) in emulsion system. Sains Malaysiana, 47(3): 511-515.

Zafarizal, A A H; Idris, Z; Abd Ghani, S S and Basri, M (2018). In vitro safety evaluation of palm tocotrienol-rich fraction nanoemulsion for topical application. J. Oil Palm Res. Vol. 30(1): 150-162.

Zainal, N H; Aziz, A A; Idris, J; Jalani, N F; Mamat, R; Ibrahim, M F; Hassan, M A and Abd Aziz, S (2018). Reduction of POME final discharge residual using activated bio-adsorbent from oil palm kernel shell. J. Cleaner Production, 182: 830-837.

Zainon, M S and Nurul, J J (2019). Cantas ${ }^{\circledR}$ a green technology for oil palm harvesting and customer satisfaction towards services quality of Cantas $^{\circledR}$ suppliers in Malaysia. International J. Engineering and Technology, 8 (1.1): 222-227.

Zaki, A; Abdul Rahim, A R; Kushairi, A and Fansuree Surin, E (2018). Factors influencing Y generation towards agribusiness entrepreneurial intention. International J. Applied Business and Economic Research, 16(2): 333-339.

Zhang, Y J; Bai, B; Lee, M; Alfiko, Y; Suwanto, A and Yue, G H (2018). Cloning and characterization of EgGDSL, a gene associated with oil content in oil palm. Scientific Reports, 8: 11406. DOI:10.1038/ s41598-018-29492-6.

Zheng, Y; Chen, C; Liang, Y; Sun, R; Gao, L; Liu, T and $\mathrm{Li}, \mathrm{D}$ (2018). Genome-wide association analysis 
of the lipid and fatty acid metabolism regulatory network in the mesocarp of oil palm (Elaeis guineensis Jacq.) based on small noncoding RNA sequencing. Tree Physiology: 1-16. DOI:10.1093/treephys / tpy091.

Zubaidah, R; Nurniwalis, A W; Chan, P L; Siti Masura, S; Siti Nor Akmar, A and Parveez, G K A (2018). Tissue-specific promoters: The importance and potential application for genetic engineering in oil palm. J. Oil Palm Res. Vol. 30(1): 1-12.

Zulina, A M; Yeong, S K; Idris, Z and Ishak, S A (2018). Combined esterification and short-path distillation for high-purity pentaerythritol ester from palm kernel for biolubricants. J. Amer. Oil Chem. Soc. DOI: 10.1002/aocs.12149.

Zulkifli, A M; Humaira, M T; Aman, Z; Rahim, A R A; Norashikin, H and Dayangnailul, M A A (2018a). Evaluating training effectiveness by understanding oil palm independent smallholder's attitude towards training. J. International Academic Research for Multidisciplinary, 6(5): 42-51.

Zulkifli, A M; Sheilyza, M I and Salleh, K M (2018b). Early impact of oil palm replanting and new planting schemes on productivity and field practices of smallholder. J. International Academic Research for Multidisciplinary, 6(4): 1-12.

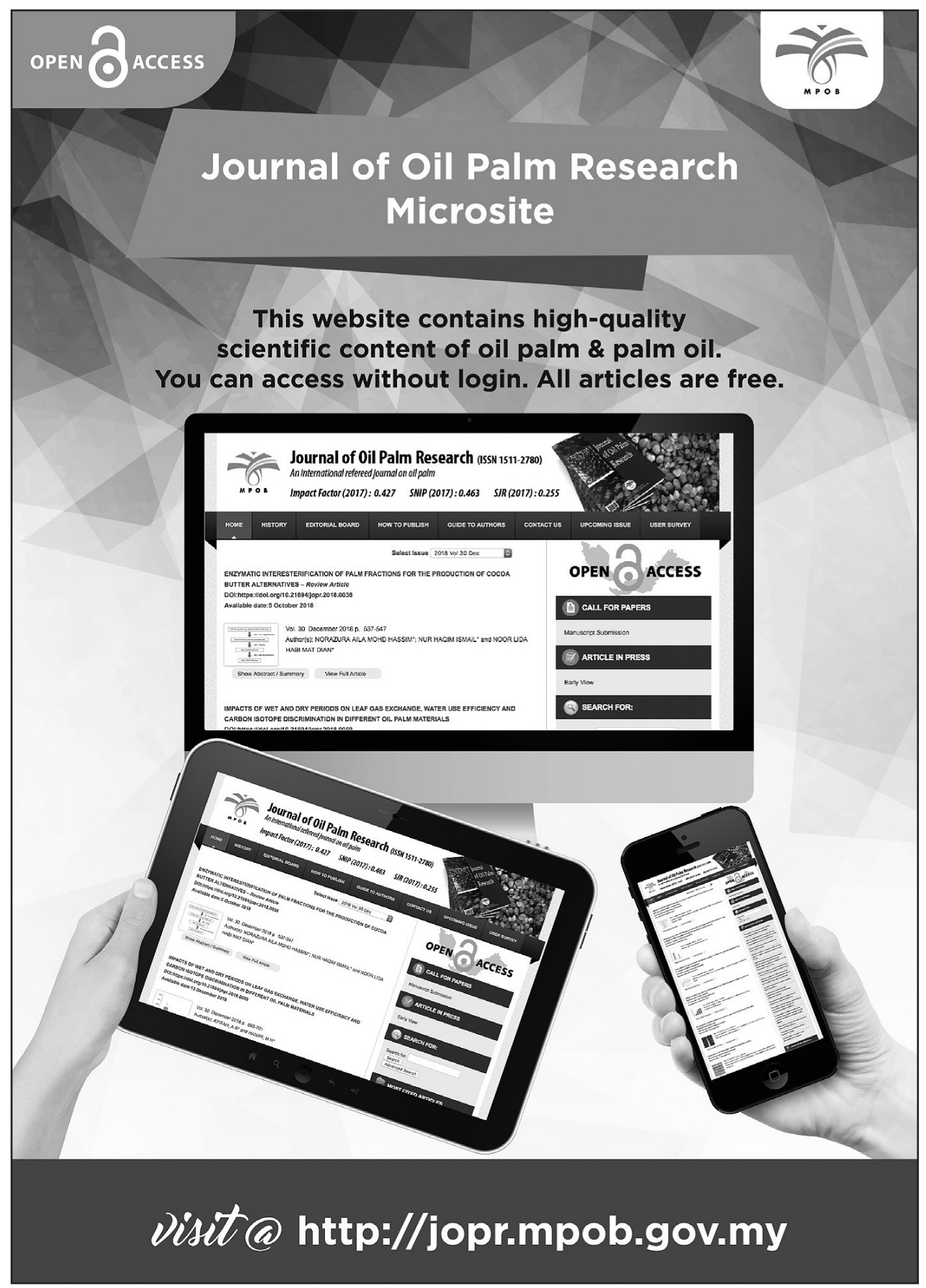

